\title{
Monosynaptic Glutamatergic Activation of Locus Coeruleus and Other Lower Brainstem Noradrenergic Neurons by the C1 Cells in Mice
}

\author{
Benjamin B. Holloway, ${ }^{1}$ Ruth L. Stornetta, ${ }^{1}$ Genrieta Bochorishvili, ${ }^{1,2}$ Alev Erisir, ${ }^{2}$ Kenneth E. Viar, ${ }^{1}$ \\ and Patrice G. Guyenet ${ }^{1}$ \\ Departments of ${ }^{1}$ Pharmacology and ${ }^{2}$ Psychology, University of Virginia, Charlottesville, Virginia 22904
}

The $\mathrm{C} 1$ neurons, located in the rostral ventrolateral medulla (VLM), are activated by pain, hypotension, hypoglycemia, hypoxia, and infection, as well as by psychological stress. Prior work has highlighted the ability of these neurons to increase sympathetic tone, hence peripheral catecholamine release, probably via their direct excitatory projections to sympathetic preganglionic neurons. In this study, we use channelrhodopsin-2 (ChR2) optogenetics to test whether the $\mathrm{C} 1$ cells are also capable of broadly activating the brain's noradrenergic system. We selectively expressed ChR2(H134R) in rostral VLM catecholaminergic neurons by injecting Cre-dependent adeno-associated viral vectors into the brain of adult dopamine- $\beta$-hydroxylase $(D \boldsymbol{\beta} H)^{\mathrm{Cre} / 0}$ mice. Most ChR2-expressing VLM neurons (75\%) were immunoreactive for phenylethanolamine $N$-methyl transferease, thus were $\mathrm{C} 1$ cells, and most of the ChR2-positive axonal varicosities were immunoreactive for vesicular glutamate transporter-2 (78\%). We produced light microscopic evidence that the axons of rostral VLM (RVLM) catecholaminergic neurons contact locus coeruleus, A1, and A2 noradrenergic neurons, and ultrastructural evidence that these contacts represent asymmetric synapses. Using optogenetics in tissue slices, we show that RVLM catecholaminergic neurons activate the locus coeruleus as well as A1 and A2 noradrenergic neurons monosynaptically by releasing glutamate. In conclusion, activation of RVLM catecholaminergic neurons, predominantly $\mathrm{Cl}$ cells, by somatic or psychological stresses has the potential to increase the firing of both peripheral and central noradrenergic neurons.

\section{Introduction}

The locus coeruleus (LC) is the largest cluster of CNS noradrenergic neurons. The activity of this nucleus is state-dependent and facilitates arousal and attention by increasing neuronal excitability in the cortex and elsewhere (Aston-Jones and Cohen, 2005; Carter et al., 2010; Berridge et al., 2012). Noradrenaline released by LC neurons also directly activates astrocyte metabolism (Sorg and Magistretti, 1991; Hertz et al., 2010). The ponto-medullary region contains several other much less studied clusters of noradrenergic neurons (A1, A2, A5, A7) that primarily target subcortical regions involved in nutrient intake and cardiorespiratory and hormonal regulations (Dahlstrom and Fuxe, 1964; Byrum and Guyenet, 1987; Ritter et al., 1998; Appleyard et al., 2007; Fenik et al., 2008; Bruinstroop et al., 2012).

LC unit activity is activated by hypotension in several species (Elam et al., 1984; Morilak et al., 1987a; Curtis et al., 1993) including humans (Mitchell et al., 2009). LC neurons are also activated by hypoglycemia, hypoxia, hypercapnia, and bacterial

Received July 9, 2013; revised Oct. 21, 2013; accepted Oct. 23, 2013.

Author contributions: B.B.H., R.L.S., G.B., A.E., and P.G.G. designed research; B.B.H., R.L.S., G.B., K.E.V., and P.G.G. performed research; B.B.H., R.L.S., G.B., A.E., and P.G.G. analyzed data; B.B.H., R.L.S., and P.G.G. wrote the paper.

This work was supported by the following grants from the National Institutes of Health (HL28785 and HL74011 to P.G.G.).

Correspondence should be addressed to Dr Patrice G. Guyenet, University of Virginia Health System, PO Box 800735, 1300 Jefferson Park Avenue, Charlottesville, VA 22908-0735. E-mail: pgg@virginia.edu.

DOI:10.1523/JNEUROSCI.2916-13.2013

Copyright $\odot 2013$ the authors $\quad 0270-6474 / 13 / 3318792-14 \$ 15.00 / 0$ infection (Elam et al., 1981; Morilak et al., 1987b; Erickson and Millhorn, 1994; Haxhiu et al., 1996; Teppema et al., 1997; Yuan and Yang, 2002; Schiltz and Sawchenko, 2007). Several observations suggest that these physiological perturbations could activate the $\mathrm{LC}$ via the $\mathrm{C} 1$ cells, a group of neurons with a dual catecholaminergic/glutamatergic phenotype which resides in the rostral ventrolateral medulla (VLM; Guyenet et al., 2013). The C1 cells densely innervate the LC (Milner et al., 1989; Pieribone and Aston-Jones, 1991; Card et al., 2006; Guyenet, 2006; Abbott et al., 2013). C1 and LC neurons respond in a qualitatively similar manner to the above-mentioned stressors (Ritter et al., 1998; Guyenet, 2006; Moreira et al., 2006; Verberne and Sartor, 2010; Abbott et al., 2013). Optogenetic stimulation of the C1 cells activates the LC in anesthetized rats (Abbott et al., 2012). Finally, the C1 neurons express VGluT2 and produce glutamatergic EPSCs (Stornetta et al., 2002a; DePuy et al., 2013). Based on light microscopy evidence, the $\mathrm{C} 1$ cells may also target additional clusters of lower brainstem noradrenergic neurons, such as the A1 and A2 cell groups located respectively in the caudal VLM and the nucleus of the solitary tract (Card et al., 2006; Abbott et al., 2013). Finally, as is well known, the $\mathrm{C} 1$ cells drive sympathetic preganglionic neurons monosynaptically, plausibly by releasing glutamate, and therefore broadly regulate the release of noradrenaline in the periphery (Morrison et al., 1989; Jansen et al., 1995; Stornetta et al., 2002b; Guyenet, 2006; Marina et al., 2011).

In the present study, we test the hypothesis that the $\mathrm{C} 1$ neurons also broadly regulate noradrenaline release within the CNS. 
We focus on three clusters of noradrenergic neurons: LC, A1 and A2 neurons. The existence of monosynaptic connections between the $\mathrm{C} 1$ cells and their noradrenergic targets is examined at the ultrastructural level and synaptic transmission between $\mathrm{C} 1$ and their noradrenergic neuronal targets is studied using channelrhodopsin-2 (ChR2) optogenetics in slices.

\section{Materials and Methods}

Animals. Animals were used in accordance with guidelines approved by the University of Virginia Animal Care and Use Committee. $\mathrm{Tg}(\mathrm{Dbh}$ cre)KH212Gsat/Mmcd mice, stock no. 032081-UCD (D $\beta H$-Cre) were obtained from the Mutant Mouse Regional Resource Center at the University of California, Davis, CA and maintained as hemizygous $\left(D \beta H^{C r e / 0}\right)$ on a C57BL/6J background. B6.Cg-Gt(ROSA)26Sor ${ }^{\text {tm9 } 9(C A G-t d T o m a t o) H z e} / \mathrm{J}$ mice (ROSA-tdTomato) were obtained from The Jackson Laboratory and crossed with the $D \beta H^{C r e / 0}$ mice to produce mice $\left(D \beta H^{\text {Cre/o }} ; R O S A\right.$-tdTomato $)$ in which noradrenergic neurons could be visualized in live slices.

Viral vectors and microinjections. The Cre-recombinase-dependent viral vectors DIO-eF1 $\alpha$-hChR2(H134R)-mCherry adeno-associated virus (AAV) and DIO-eF1 $\alpha$-ChR2(H134R)-eYFP AAV (both serotype 2; Atasoy et al., 2008) were obtained from the University of North Carolina Vector core (Chapel Hill, NC) at a titer of $10^{12}$ viral particles per milliliters. Twenty-eight, 6- to 13-week-old mice (median 9; 14 males, 14 females) were anesthetized with a mixture of ketamine $(100 \mathrm{mg} / \mathrm{kg})$ and dexmedetomidine $(0.2 \mathrm{mg} / \mathrm{kg})$ given intraperitoneally. After reaching an adequate plane of anesthesia (unresponsive to paw pinch and no corneal reflex) animals were placed into a modified stereotaxic device (Kopf) on a thermostatically controlled heating pad and received three injections of undiluted virus (240-360 $\mathrm{nl}$ total volume) into the left rostral VLM (RVLM) under electrophysiological guidance as described previously (Abbott et al., 2013).

Electrophysiology. Four to 12 weeks after AAV2 injection, the mice were anesthetized with a mixture of ketamine $(120 \mathrm{mg} / \mathrm{kg})$ and xylazine $(12 \mathrm{mg} / \mathrm{kg}$ ) given intraperitoneally, and after becoming completely anesthetized (unresponsive to hindpaw pinch) were decapitated. The brainstem was sectioned with a vibrating microtome in the transverse plane in ice-cold, N-Methyl-D-glucamine (NMDG)-substituted artificial CSF (ACSF) containing the following (in mM): $92 \mathrm{NMDG}, 2.5 \mathrm{KCl}, 1.25$ $\mathrm{NaH}_{2} \mathrm{PO}_{4}, 10 \mathrm{MgSO}_{4}, 0.5 \mathrm{CaCl}_{2}, 20$ HEPES, $30 \mathrm{NaHCO}_{3}$, 25 glucose, 2 thiourea, $5 \mathrm{Na}$-ascorbate, $3 \mathrm{Na}$-pyruvate $(\sim 300 \mathrm{mOsm} / \mathrm{kg})$. After $10 \mathrm{~min}$ at $33^{\circ} \mathrm{C}, 200$ - to $300-\mu \mathrm{m}$-thick slices were transferred to aerated physiological extracellular ACSF containing the following (in mM): $119 \mathrm{NaCl}$, $2.5 \mathrm{KCl}, 1.25 \mathrm{NaH}_{2} \mathrm{PO}_{4}, 2 \mathrm{MgSO}_{4}, 2 \mathrm{CaCl}_{2}, 26 \mathrm{NaHCO}_{3}, 12.5$ glucose, 2 thiourea, $5 \mathrm{Na}$-ascorbate, $3 \mathrm{Na}$-pyruvate, and maintained at room temperature $\left(23^{\circ} \mathrm{C}\right)$. All recordings were performed at room temperature in submerged slices continuously perfused with aerated physiological ACSF. Glass pipettes (2-6 M $\Omega$ tip resistance) were filled with a solution containing the following (in $\mathrm{mM}$ ): $140 \mathrm{~K}$-gluconate, 10 HEPES, 10 trisphosphocreatine, 3 ATP-Na, 0.3 GTP-Na, 1 EGTA, $2 \mathrm{MgCl}_{2}$, pH 7.3. EPSCs were recorded at V-hold of $-60 \mathrm{mV}(-74 \mathrm{mV}$ after junction potential correction). In selected experiments, K-gluconate was replaced with cesium-methanesulfonate $(140 \mathrm{~mm})$ and recordings were made at Vhold of $-70 \mathrm{mV}$ and $+9 \mathrm{mV}$ (respectively, -80 and $0 \mathrm{mV}$ after junction potential correction). The calculated $\mathrm{E}[\mathrm{Cl}-]$ was $-88 \mathrm{mV}$. Biocytinfilled electrodes $(0.2 \%)$ were used to label the recorded cells. Recordings were performed using a Multiclamp 700B amplifier and pClamp 10 software (Molecular Devices). Signals were low-pass filtered at $4 \mathrm{kHz}$ and digitized at $10 \mathrm{kHz}$. Only cells with series resistance that remained $<25$ $\mathrm{M} \Omega$ were included in the analysis. Further analysis (event-triggered averages, event-triggered histograms, EPSC detection and counting, curve fitting of PSC decay and measurement of decay time-constant) was done using Spike2 version 7.10 software (CED). Photostimulation of ChR2expressing neurons, axons and nerve terminals was done with a $200-\mu \mathrm{m}-$ diameter optical fiber coupled to a $473 \mathrm{~nm}$ DPSS laser (IkeCool; $1 \mathrm{~ms}$ pulses, $5 \mathrm{~mW}$ steady-state output) as previously described (Depuy et al., 2013). The optical fiber, held at 40 degrees from the horizontal, was positioned such that the tip was $150 \mu \mathrm{m}$ above and $250 \mu \mathrm{m}$ lateral to each recorded neuron. This setup intensely illuminated an ellipse of $\sim 0.342$ $\mathrm{mm}^{2}$, which produced an estimated average irradiance of $\sim 14 \mathrm{~mW} / \mathrm{mm}^{2}$ comparable to that used by others previously (Grossman et al., 2013). Delivery of optical pulses was triggered by a digitizer (Digidata 1440A, Molecular Devices) controlled by episodic protocols run in pClamp 10 (Molecular Devices). The output of the laser/fiber was calibrated for $5 \mathrm{~mW}$ steady-state output before each experiment. The following drugs were used: tetrodotoxin (TTX; Fisher Scientific, final concentration $1 \mu \mathrm{M}$ ); 4-aminopyridine (4-AP; Sigma-Aldrich; 100-200 $\mu \mathrm{M}$ ); kynurenic acid (Sigma-Aldrich; $1 \mathrm{~mm}$ ), 6-cyano7-nitroquinoxaline-2,3-dione (CNQX, Tocris Bioscience; $10 \mu \mathrm{M}$ ), D-(-)-2Amino-5-phosphonopentanoic acid (AP-5, Sigma-Aldrich; $50 \mu \mathrm{M}$ ).

Slices from electrophysiological recording experiments containing biocytin-filled cells were fixed in $4 \%$ paraformaldehyde (PFA) from 2 to $5 \mathrm{~d}$. Sections were rinsed and incubated first in blocking solution using a Triton concentration of $0.5 \%$ to enhance antibody penetration in thicker tissue and then in primary antibodies (described below) to detect tyrosine hydroxylase (TH) and dsRed or EYFP. Slices were then rinsed and incubated with appropriate secondary antibodies as well as with NeutrAvidin-Dylight-649 (Fisher Scientific), rinsed, mounted and covered as described below.

Fluorescent light microscopy for distribution of PNMT and to confirm $t d$ Tomato expression in catecholaminergic neurons. Lower brainstem sections from $3 \mathrm{D} \beta H^{\mathrm{Cre} / 0}$ mice injected 5 weeks prior with DIO-eF1 $\alpha$-eYFP AAV2 were examined to determine which proportion of the transduced neurons expressed both TH and phenylethanolamine- $\mathrm{N}$-methyl transferase (PNMT), i.e., were $\mathrm{C} 1$ cells. These mice were anesthetized with an overdose of pentobarbital and perfused transcardially with $10 \mathrm{ml}$ heparinized saline followed by $80 \mathrm{ml}$ of $2 \%$ PFA. The brains were postfixed in $2 \%$ PFA for 2-5 d. Brainstem sections from three $D \beta H^{\text {Cre/o }} / R O S A 26-$ $t d$ Tomato mice were also examined histologically to test whether the red fluorophore, tdTomato, was confined to catecholaminergic neurons. Thirty-micrometer-thick transverse sections were cut with a vibrating microtome and collected into a cryoprotectant solution and stored at $-20^{\circ} \mathrm{C}$ before further processing. All histological procedures were done with free-floating sections. For fluorescent immunohistochemistry, sections were rinsed, blocked with $10 \%$ normal horse serum in $100 \mathrm{~mm}$ Tris-Saline containing $0.1 \%$ Triton X-100 and incubated in primary antibodies diluted in this blocking solution for $16-18 \mathrm{~h}$ at $4^{\circ} \mathrm{C}$ as follows: sheep anti-TH (Millipore; 1:1000), rabbit anti-dsRed (Clontech Laboratories; 1:500) or chicken anti-GFP (AVES; 1:1000) and/or rabbit anti-PNMT (generously provided by Dr. Martha Bohn, Northwestern University Medical School, Chicago, IL; 1:3000; Bohn et al., 1987). Sections were then rinsed and incubated for 45-60 $\mathrm{min}$ in appropriate secondary antibodies as follows: DyLight 649 anti-sheep IgG, Cy3 anti-rabbit IgG, AlexaFluor 488 anti-chicken IgY all raised in donkey and at 1:200 (Jackson ImmunoResearch) then rinsed, mounted on gelatinized glass slides, dehydrated through a graded series of alcohols, and covered with DPX.

Light microscopy for imaging VGluT2 in terminals from C1 neurons and to examine close appositions from $C 1$ neurons onto A1, A2, and A6 (LC) neurons. For fluorescent imaging of close appositions as well as for determination of VGluT2 immunoreactivity in terminals of $\mathrm{C} 1$ or A1 neurons, a one in three series of $30-\mu \mathrm{m}$-thick coronal sections were processed as described above. A guinea pig anti-VGluT2 antibody (Millipore, AB2251; 1:2000) was substituted for the PNMT antibody. The secondary antibody for the VGluT2 primary was a Cy3-tagged anti-guinea pig IgG (Jackson Immunoresearch; 1:200) used exactly as the other secondaries described above.

For bright-field imaging of close appositions of terminals from ChR2mCherry labeled $\mathrm{C} 1$ neurons onto TH cells in A1, A2, and A6 (LC), sections from $3 \mathrm{D} \beta \mathrm{H}^{\mathrm{Cre} / 0}$ mice previously injected with DIO-eF1 $\alpha$ mCherry as described above were incubated in blocking solution as described, rinsed, and incubated in $1 \%$ hydrogen peroxide, then rinsed and incubated in rabbit anti-dsRed (1:500; recognizes mCherry) in $0.5 \%$ "TNB" (proprietary blocking reagent, PerkinElmer) prepared in $100 \mathrm{~mm}$ Tris-saline for $16-18 \mathrm{~h}$ at $4^{\circ} \mathrm{C}$. Sections were then rinsed and incubated in biotinylated donkey anti-rabbit IgG (Jackson Immunoresearch; 1:1000) for 45-60 min, rinsed, and incubated in $\mathrm{ABC}$ solution according to manufacturer's instructions (Vectastain "Elite"; Vector Laboratories) for $45 \mathrm{~min}$, then rinsed and incubated with 3,3'diaminobenzidine (DAB) 
with nickel enhancement using the DAB kit according to the manufacturer's instructions (Vector Laboratories) resulting in a black reaction product. Sections were then rinsed and incubated in sheep anti-TH (1: 1000 ) prepared in $0.5 \%$ TNB in $100 \mathrm{~mm}$ Tris-saline for $16-18 \mathrm{~h}$ at $4^{\circ} \mathrm{C}$. Sections were then rinsed and incubated in biotinylated donkey antisheep IgG (Jackson Immunoresearch; 1:000) for 45-60 min, rinsed and incubated in $\mathrm{ABC}$ solution (Vector Laboratories) for $45 \mathrm{~min}$, then rinsed and incubated in DAB using a kit according to the manufacturer's instructions (Vector Laboratories) resulting in a brown reaction product. Sections were then rinsed, mounted, and covered as described above.

Light microscopic examination of putative terminals from $\mathrm{Cl}$ or Al neurons. Slides were examined using a Zeiss Axioskop2 and photographed with a Zeiss MRC camera. Computer-assisted mapping of the neurons of interest was done as previously described (Bochorishvili et al., 2012; Stornetta et al., 2013). For analysis of fluorescent terminals, 10 micron Z-stacks at $0.3 \mu \mathrm{m}$ increments were taken through the tissue with filter sets at appropriate wavelengths to discriminate the various fluorophores without "bleed through" (wavelengths listed as excitation, beam splitter, emission; for Cy3: 545, 570, 605; for AlexaFluor 488: 500, 515, 535; for AlexaFluor 649: 640, 660, 690). For the $100 \times$ objective used to determine bouton double labeling and close appositions, the resulting digital images were 15.2 pixels $/ \mu \mathrm{m}$. A bouton was considered to be double labeled if both fluorophores were in focus and coincident through at least two levels of the Z-stack. For illustration of close appositions, Z-stack images were subjected to 3D blind deconvolution through seven iterations using the AutoQuant X3 software (Media Cybernetics). Deconvoluted stacks were then processed with Volocity software (version 4.4, Improvision) for $3 \mathrm{D}$ rendering and confirmation of close appositions. A close apposition was defined as two objects labeled with two separate fluorophores overlapping at least 7 pixels in each Z-level, and at least in two consecutive Z-levels (Corson and Erisir, 2013). The size of this overlap represents an apposition of $\sim 0.45 \mu \mathrm{m}$ in length.

Electron microscopy methods and analysis. For ultrastructural analysis, two $D \beta H^{C r e / 0}$ mice injected 5 weeks prior with DIO-eF1 $\alpha$-ChR2mCherry AAV2 were anesthetized as above and perfused transcardially, first with $20 \mathrm{ml}$ of heparinized saline $(1000 \mathrm{U} / \mathrm{ml})$, and then with fixative ( $25 \mathrm{ml}$ of $2 \%$ PFA with $3.75 \%$ acrolein, Electron Microscope Sciences; followed by $30 \mathrm{ml}$ of $2 \%$ PFA). Brains from these animals were then postfixed for at least $3 \mathrm{~h}$ in $2 \%$ PFA before sectioning with a vibrating microtome into $30-\mu \mathrm{m}$-thick transverse sections. The tissues were blocked in $0.8 \%$ BSA with $0.03 \%$ Triton X-100 then incubated in rabbit anti-DsRed (Clontech) at 1:500 made in blocking solution at $4^{\circ} \mathrm{C}$ for $16-18 \mathrm{~h}$, rinsed, and incubated for $60 \mathrm{~min}$ in biotinylated donkey antirabbit IgG (1:400, Jackson Immunoresearch). Tissues were rinsed and incubated for $60 \mathrm{~min}$ in $\mathrm{ABC}$ (Vector), rinsed and incubated in $\mathrm{DAB}$ (Vector Laboratories) as above. Sections for immunogold-silver staining were placed in mouse anti-TH (1:1000; ImmunoStar, catalog \#22941) and incubated for $16-18 \mathrm{~h}$ at $4^{\circ} \mathrm{C}$. Sections were rinsed and incubated for $30 \mathrm{~min}$ in washing buffer (PBS containing $0.8 \% \mathrm{BSA}, 0.1 \%$ fish gelatin, and $3 \%$ normal goat serum). Tissues were subsequently incubated for $2 \mathrm{~h}$ in washing buffer containing $1 \mathrm{~nm}$ gold-conjugated donkey anti-mouse IgG (1:50; Aurion, Electron Microscopy Sciences). The sections were next rinsed in washing buffer, followed by a rinse in PBS, and then incubated in $2.5 \%$ glutaraldehyde in PBS for $10 \mathrm{~min}$. The tissue was subsequently rinsed in PBS and transferred to sterile, untreated culture well plates for a series of $1 \mathrm{~min}$ rinses in PBS and then in $0.2 \mathrm{~m}$ sodium citrate buffer, $\mathrm{pH}$ 7.4. Rinses were followed by a silver enhancement reaction at room temperature using IntenSEM silver kit reagents according to manufacturer's instructions (GE Healthcare). The sections were handled with wooden applicator sticks and gently swirled throughout the silver enhancement procedure for 4-6 min. Sections were then rinsed in sodium citrate buffer and $100 \mathrm{~mm}$ phosphate buffer. Sections were then incubated in $1 \%$ osmium tetroxide and $1 \%$ uranyl acetate (Electron Microscopy Sciences) for $90 \mathrm{~min}$. Tissues were rinsed, transferred to porcelain dishes, dehydrated through a series of increasing ethanol concentrations $(30,50,70$, and $95 \%)$, and then placed into glass vials containing $100 \%$ ethanol. Finally, the tissue sections were treated with propylene oxide ( $2 \times 10 \mathrm{~min})$ and incubated in a 1:1 mixture of propylene oxide and embedding resin Embed-812 (Electron Microscopy Sci- ences). This mixture was then replaced with straight Embed-812 which infiltrated the sections for 16-18 h. The tissue was embedded between sheets of plastic (Aclar), flattened, and cured for at least $72 \mathrm{~h}$ at $62^{\circ} \mathrm{C}$. Then flat-embedded sections were examined with a light microscope to detect immunogold-labeled TH cells and DAB-labeled $\mathrm{C} 1$ projection fields in the A1 and A2 noradrenergic cell clusters. The regions of interest were further trimmed and repolymerized at the bottom of Beem capsules. The block was trimmed to a $2 \times 1 \mathrm{~mm}$ trapezoidal block that spanned the A1 or A2 and contained the TH-immunoreactive cells. Ultrathin sections $(70-90 \mathrm{~nm})$ were cut at a plane near parallel to the surface of $30 \mu \mathrm{m}$ sections using a Leica Ultracut UCT. This approach ensures that the top $5-10 \mu \mathrm{m}$ of the sections, where immunolabeling is present, are sectioned to yield a wide $(100-200 \mu \mathrm{m})$ strip of labeled ultrathin tissue. Ultrathin sections were collected onto copper mesh grids in series of 7-10 sections per grid. Tissue was analyzed with a JEOL 1230 transmission electron microscope, and micrographs were captured with an ultra high resolution digital imaging $(4 \mathrm{~K} \times 4 \mathrm{~K})$ camera (Scientific Instruments and Applications). Adobe Photoshop was used to adjust image contrast and illumination, and then images were exported into the Canvas drawing software (Version 10, ACD Systems).

Antibody characterization. All antibodies used are listed in the Journal of Comparative Neurology antibody database and have been previously characterized as follows:

PNMT antibody raised in rabbits against purified rat adrenal extract was obtained from Dr. M. Bohn (Northwestern University, Chicago, IL; Bohn et al., 1987) and showed a labeling pattern similar to that seen in rats using identical conditions as previously published (Verberne et al., 1999).

TH antibody raised in sheep (Millipore) against native tyrosine hydroxylase from rat pheochromocytoma labels one band of expected length in Western blots of mouse brain lysates (from the manufacturer's information). The labeling pattern is identical to that seen in mouse brain in previous publications from the lab using identical conditions (DePuy et al., 2013).

TH antibody raised as a mouse monoclonal antibody against $\mathrm{TH}$ purified from PC12 cells recognizes an epitope in the catalytic core region of the $\mathrm{TH}$ molecule where extensive species homology exists. Western blots of HEK293 cells transfected with human TH probed with the antibody show one expected $60 \mathrm{kDa}$ band (the manufacturer's information). The labeling pattern is identical to that seen in mouse brain in previous publications from the laboratory using identical conditions (DePuy et al., 2013).

VGluT2 antibody raised in guinea pig against a peptide corresponding to the C-terminal of rat VGluT2 recognizes one band of expected size on Western blots of rat brain lysate (from the manufacturer's information). Labeling is absent in terminals from neurons where VGluT2 is eliminated by cre-mediated recombination with a floxed VGluT2 allele (Kaur et al., 2013). The labeling pattern is identical to that seen in mouse brain in previous publications from the laboratory using identical conditions (DePuy et al., 2013).

GFP antibody raised in chicken against recombinant GFP protein shows labeling only in tissue injected with viral vectors expressing eYFP. The antibody labeling matches exactly with nonamplified eYFP fluorescence.

DsRed antibody raised in rabbits against DsRed-Express, a variant of Discosoma sp. red fluorescent protein recognizes both $\mathrm{N}$ - and C-terminal fusion proteins containing dsRed variants in mammalian cell extracts (from the manufacturer's information). This antibody shows labeling only in tissue injected with viral vectors expressing mCherry or in tissue from tdTomato reporter mice. The antibody labeling matches exactly with nonamplified mCherry or tdTomato fluorescence.

Statistics. Statistical significance was set at $p<0.05$. Data that passed the D'Agostino-Pearson test for normality are expressed as mean \pm SEM, whereas non-normally distributed values are described by range and median. Degrees of freedom are listed for parametric tests. To compare two groups we used a paired $t$ test or Wilcoxon signed rank test. To compare multiple groups, we used the Kruskal-Wallis test or, for repeated measures, the Friedman test followed by Dunn's test to assess intergroup differences. All statistics were done using GraphPad Prism software (version 6). 


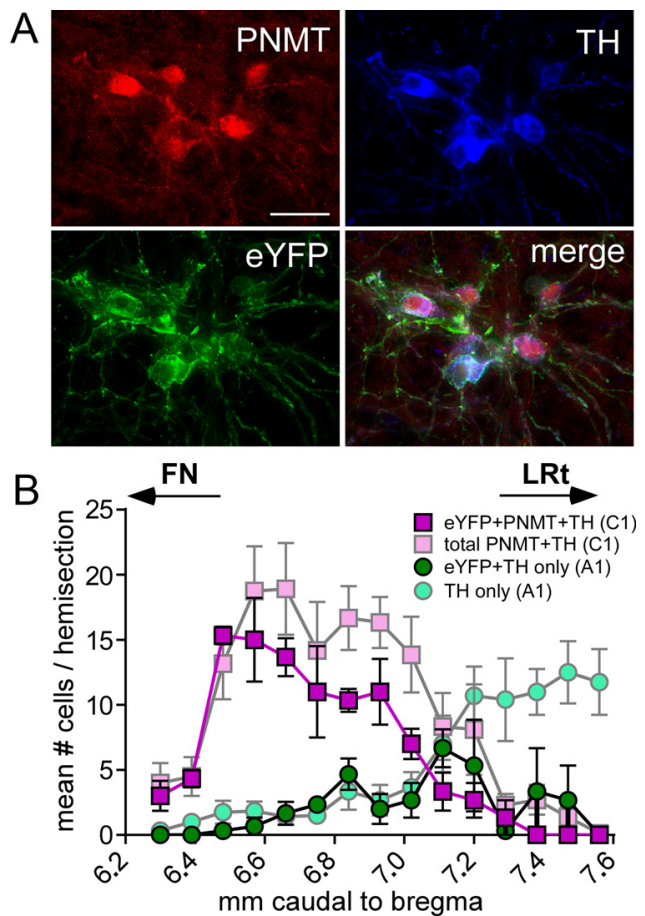

Figure 1. Selective expression of ChR2-eYFP in C1 cells. $A$, Cluster of ChR2-eYFP-positive RVLM neurons that were immunoreactive for both TH and PNMT and therefore qualified as $\mathrm{C1}$ neurons. Scale bar, $30 \mu \mathrm{m}$. This transverse section was located $\sim 6.6 \mathrm{~mm}$ caudal to bregma after Paxinos and Franklin, (2004). B, Rostrocaudal distribution of C1 (immunoreactive for both PNMT and TH; light pink symbols with gray lines and error bars) and presumptive A1 neurons (immunoreactive for TH only; light green with gray lines and error bars; mean $\pm \mathrm{SE}$ of six mice). Rostrocaudal distribution of ChR2-eYFP-positive C1 neurons (PNMT- and TH-ir; purple squares with purple lines and black errors bars, average of three mice) and ChR2-eYFP-positive A1 neurons (TH-ir and eYFP-ir, but PNMT-negative; dark green with black lines and error bars, same three mice). Note that the percentage of (1 cells expressing ChR2-eYFP in the RVLM is much higher than expression of ChR2-eYFP in the TH-ir only (A1) neurons at more caudal levels. Abscissa indicates the level of the transverse sections in $\mathrm{mm}$ caudal to bregma after Paxinos and Franklin (2004). The location of the FN and that of the LRt are indicated for orientation (for LRt, starting point of arrow defines level where the anterior portion of this nucleus ends). Arrows indicate that these structures extend beyond the levels represented.

\section{Results}

\section{Selective expression of ChR2 by RVLM catecholaminergic} neurons

We examined the distribution of neurons with $\mathrm{TH}$-immunoreactive (ir), PNMT-ir, or both in the VLM of 6 mice using a 1-in-3 series of transverse sections. As in rats, the PNMT-ir neurons ( $\mathrm{C} 1$ neurons) were predominantly confined to the RVLM, namely between the caudal end of the facial motor nucleus (FN) and the rostral pole of the lateral reticular nucleus (LRt; Fig. 1). Caudal to the rostral pole of the LRt, the vast majority of the TH-ir cells lacked PNMT and were therefore A1 noradrenergic neurons. A small number of A1 (THpositive and PNMT-negative) neurons were also present in the RVLM (Fig. 1B).

DIO-eF1 $\alpha$-ChR2-eYFP AAV2 was injected into the left RVLM of three $D \beta H^{C r e / 0}$ mice. After 5 weeks, we mapped the location of the ChR2-eYFP-expressing neurons, also in a 1-in-3 series of transverse sections. These neurons were confined to the VLM. None were found in the dorsal medulla, the contralateral VLM or the pons consistent with the lack of retrograde propagation of AAV serotype 2. Almost all eYFP-positive neurons were TH-ir (respectively 99, 100, and 94\% colocalization in three mice; Fig. $1 A, B)$ and most $(69,83$, and $70 \%$, respectively) also contained PNMT immunoreactivity (Fig. $1 A, B$ ). In short, ChR2 was selectively expressed by RVLM catecholaminergic neurons and $74 \%$ of those catecholaminergic cells were detectably PNMT-ir hence, by definition, C1 neurons (Hokfelt et al., 1974). The balance were TH-ir neurons without detectable PNMT, therefore presumably A1 cells.

\section{ChR2-expressing RVLM catecholaminergic neurons innervate lower brainstem noradrenergic neurons}

The axonal projections of ChR2-expressing RVLM catecholaminergic neurons were examined in two mice using the DIO-eF1 $\alpha$-ChR2-mCherry AAV2 vector and in three mice injected with the DIO-eF1 $\alpha$-eYFP AAV2 vector which also labels catecholaminergic neurons selectively $(>98 \%)$ when injected into the VLM of $D \beta H^{\mathrm{Cre} / 0}$ mice (Abbott et al., 2013; DePuy et al., 2013). A dense network of mCherry-positive axonal varicosities covered the entire LC (Fig. 2A). Dense projections also covered the soma and dendrites of $\mathrm{A} 1$ and $\mathrm{A} 2$ neurons (Fig. $2 B, C)$. Close appositions between eYFP-ir axonal varicosities and $\mathrm{TH}$-ir somata or dendrites were commonly observed using light and immunofluorescence methods. Close appositions on $\mathrm{A} 1$ and $\mathrm{A} 2$ neurons from a $3 \mathrm{D}$ rendering are shown in Figure 2D,E.

Ultrastructural evidence for synapses between $\mathrm{C} 1$ cells and LC neurons was not sought because it has already been provided in rats (Milner et al., 1989; Abbott et al., 2012) and we obtained optogenetic evidence for monosynaptic connectivity between these cells (shown below). We therefore focused our ultrastructural studies on the $\mathrm{A} 1$ and $\mathrm{A} 2$ neurons. For these experiments, we used tissue from three DIO-eF1 $\alpha$-ChR2-mCherry-AAV2 injected mice processed for simultaneous detection of mCherry and TH immunoreactivity.

Within the A1 noradrenergic neuron-rich region of the VLM (caudal to area postrema level) mCherry-ir (DABlabeled) profiles consisted exclusively of unmyelinated axons or nerve terminals. Immunogold-silver labeling for $\mathrm{TH}$ was observed within perikarya, dendrites, and nerve terminals. A representative asymmetric synapse between an mCherry-ir varicosity and a $\mathrm{TH}$-ir dendrite (A1 region) is shown in two serial sections in Figure $3 A 1, A 2$. A total of 78 mCherry-ir axonal profiles were observed within the A1 region. Of these, 63 were axonal varicosities that directly contacted dendrites. Fifty-one (80\%) of these dendritic contacts showed asymmetric synaptic junctions and $12(19 \%)$ were symmetric. The 15 other mCherry-ir profiles made close appositions but no detectable synapses.

Similar results were found in the A2 noradrenergic neuronrich region of the nucleus of the solitary tract at and caudal to the level of the area postrema. mCherry-ir (DAB-labeled) profiles also consisted exclusively of unmyelinated axons or nerve terminals and immunogold-silver labeling for $\mathrm{TH}$ was observed within perikarya, dendrites, and nerve terminals. The four serial sections shown in Figure 3B1-B4 show a mCherry-ir fiber establishing two synaptic junctions with a $\mathrm{TH}$-ir dendrite located in the A2 region. The synapse illustrated in Figure $3 A 1, A 2$ is a typical asymmetric synapse whereas the synapse in Figure 3B1,B2 is a perforated synapse, i.e., the cross-section of a synapse that appears as two postsynaptic densities separated by a small gap. Both presynaptic and postsynaptic profiles contained silver grains and therefore were TH-ir. We identified 79 synaptic contacts between mCherry-ir varicosities and $\mathrm{TH}$-ir profiles, most of which $(N=70 ; 89 \%)$ were asymmetric and the rest symmetric $(N=9$, $11 \%)$. Another 11 mCherry-ir synaptic varicosities made close ap- 
positions with a $\mathrm{TH}$-ir profile but no synapse was detected. Dense core vesicles (Fig. 3 , examples marked with asterisks) consistent with catecholamine-releasing organelles were detected within the more lightly labeled mCherry-ir varicosities.

\section{Photostimulation of ChR2-labeled C1 axons activates LC neurons monosynaptically in slices}

Seventy-nine LC neurons were recorded in transverse slices from 15 mice $(9$ males, 6 females). The LC was identified as the medium-sized, high-neuron density population below the third ventricle and medial to the superior cerebellar peduncle and trigeminal mesencephalic nucleus (Fig. 4A). The dense innervation of LC from C1 AAV2 transfected neurons (seen as either eYFP or mCherry fluorescent terminals) could also be visualized in the slice (Fig. $4 A$ ) and helped to guide placement of the recording electrode. Seven LC neurons were recorded and filled with biocytin in slices prepared from three $D \beta H^{C r e / 0} /$ ROSA26-tdTomato mice. These neurons exhibited red (tdTomato) fluorescence, thus were catecholaminergic LC neurons. Thirty-two biocytin-filled neurons were recorded in slices prepared from 5 $D \beta H^{\mathrm{Cre} / 0}$ mice previously injected with DIO-eF1 $\alpha$-ChR2-mCherry AAV2. These neurons were shown to be either TH-ir and/or surrounded by other LC neurons (Fig. 5B, left column).

Pulses of laser light (1 ms, $5 \mathrm{~mW}, 473 \mathrm{~nm})$ produced PSCs in $53 \%(42 / 79)$ of the LC neurons sampled (Fig. 4B1). Occasionally, a laser pulse failed to evoke a PSC (Fig. 4B1, red traces; failure rate $19 \pm 4 \%, N=23)$. The PSC amplitude, determined by eventtriggered signal averaging, including failures, was $34.8 \pm 5.0 \mathrm{pA}$ (range $8-107 \mathrm{pA} ; N=23$; Fig. 4B2). Failure rates, determined by peri-event histograms (Fig. 4B3), were calculated for all photoresponsive LC neurons $(N=23)$. Failure rates from LC neurons shown to be monosynaptically innervated by RVLM CA neurons, based on the recovery of synaptic transmission after addition of 4-AP and TTX ( $N=9$, details below), never exceeded 39\% and did not differ significantly from untested LC neurons $(0-38.7 \%$, median $20 \%, N=9$ vs $0-73.3 \%$, median $6.7 \%$; $N=14$ ).

In 14 LC neurons, recordings were made with cesium-filled electrodes to enable voltage-clamp recordings at -80 and 0 $\mathrm{mV}$ (junction potential-corrected $V_{\text {Hold }}$ ). The EPSC evoked by the $0.5 \mathrm{~Hz}$ laser stimulation was greatly decreased in amplitude when the neurons were held at $0 \mathrm{mV}$ (from $32.3 \pm 6.9-$ $1.4 \pm 0.1 \mathrm{pA}, N=12, p=0.0005$, Wilcoxon-matched pairs) but always remained inward (Fig. 4B4). Thus, low-frequency photostimulation of the $\mathrm{C} 1$ axons does not produce chloridemediated IPSCs in LC neurons.

Higher-frequency photostimulation $(2,5,10 \mathrm{~Hz}$ for $10 \mathrm{~s}$; K-gluconate-filled pipettes) produced sustained barrages of EPSCs in LC neurons (Fig. 4C1). The EPSC rate increased during the first $2-4 \mathrm{~s}$ of the train before reaching a steady-state (Fig. 4C1). The light-evoked EPSCs tended to be desynchronized from the light pulses when the stimulus was delivered at high-frequency (10 Hz; Fig. 4C2), and their rate largely ex-

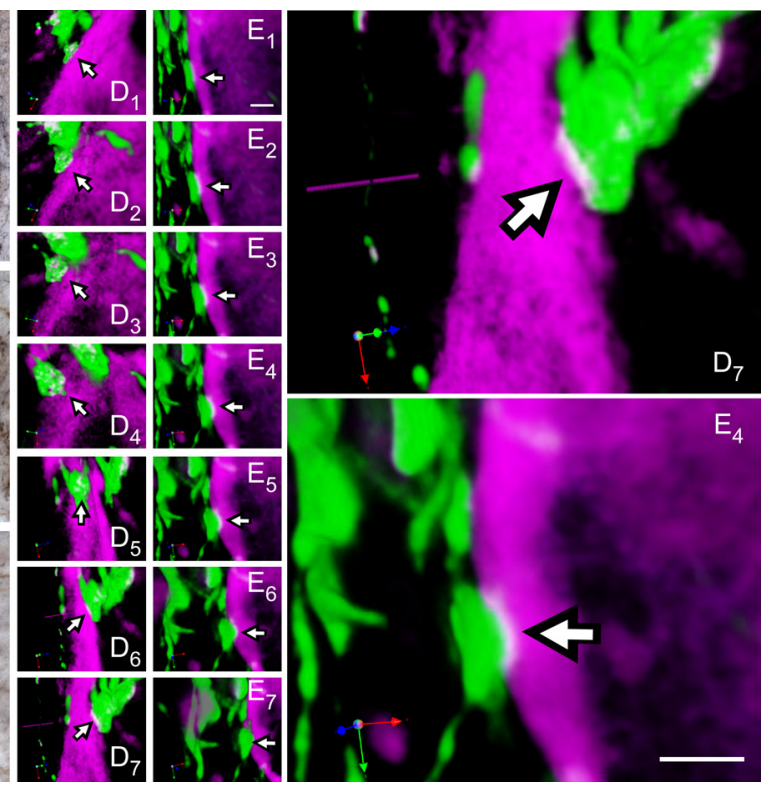

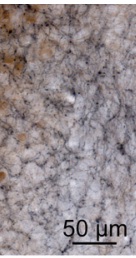

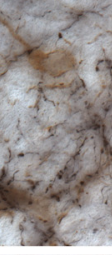

$\underline{25 \mu \mathrm{m}}$

Figure 2. Innervation of lower brainstem noradrenergic neurons by the C1 cells. $\boldsymbol{A}$, mCherry-ir axonal varicosities (black, DAB, enlargement for $E 4,1 \mu \mathrm{m}$ for enlargements of $\mathbf{D 7}$ and $E 4$

ceeded the photostimulus rate (Fig. 4C1-C3). This result can probably be explained by the relatively slow kinetics of ChR2(H134R) which leads to a sustained depolarization and probable intracellular calcium build-up during highfrequency stimulation (Lin, 2011). The hypothesized intracellular calcium accumulation could explain the rapid but noninstantaneous return of EPSC frequency rate to base line values after the stimulus train ( $\tau=1.6 \mathrm{~ms}$; Fig. $4 C 3$ and inset). In current-clamp, high-frequency photostimulation at $10 \mathrm{~Hz}$ reversibly activated $\mathrm{LC}$ neuronal firing from $1.9 \pm 0.4 \mathrm{~Hz}$ to $3.1 \pm 0.7 \mathrm{~Hz}(N=8, p=0.019$, Friedman test; Fig. $4 D)$.

Bath application of the broad-spectrum glutamatergic antagonist kynurenate $(1 \mathrm{~mm})$ reversibly decreased the amplitude of the postsynaptic current (4 cells, 67.0-82.1\% attenuation, median $76.7 \%$; $p=0.0046$; Fig. 4E1,E2). To determine whether the excitatory $\mathrm{C} 1$ input to the LC was monoor poly-synaptic, we blocked voltage-gated sodium $\left(\mathrm{Na}_{\mathrm{v}}\right)$ channels with $1 \mu \mathrm{M}$ TTX, then applied 100-200 $\mu \mathrm{M}$ 4-AP to block $\mathrm{K}_{\mathrm{v}}$ channels (Shu et al., 2007). TTX eliminates action potential-dependent EPSCs, and thus eliminates any polysynaptic event, whereas 4-AP augments the light-induced, direct depolarization of ChR2-positive nerve terminals (Petreanu et al., 2009). TTX eliminated evoked EPSCs (Fig. 4F1,F2), indicating that these events were action-potential-dependent. The addition of 4-AP reinstated the EPSCs, though these events were typically broader (decay time constant, $20.5 \pm 5.4 \mathrm{~ms}$ vs $10.0 \pm 1.4 \mathrm{~ms} ; p=0.0547$, Wilcoxon matched pairs), their onset latency delayed $(14.1 \pm 1.3 \mathrm{~ms}$ vs $5.1 \pm 0.4 \mathrm{~ms} ; p=$ 0.0039 , Wilcoxon matched pairs), and their latency to peak longer $(26.7 \pm 0.3 \mathrm{~ms}$ vs $9.5 \pm 0.7 \mathrm{~ms} ; \mathrm{df}=8, p=0.006$, paired $t$ test) than before drug application (Fig. 4F1). Evoked EPSCs 

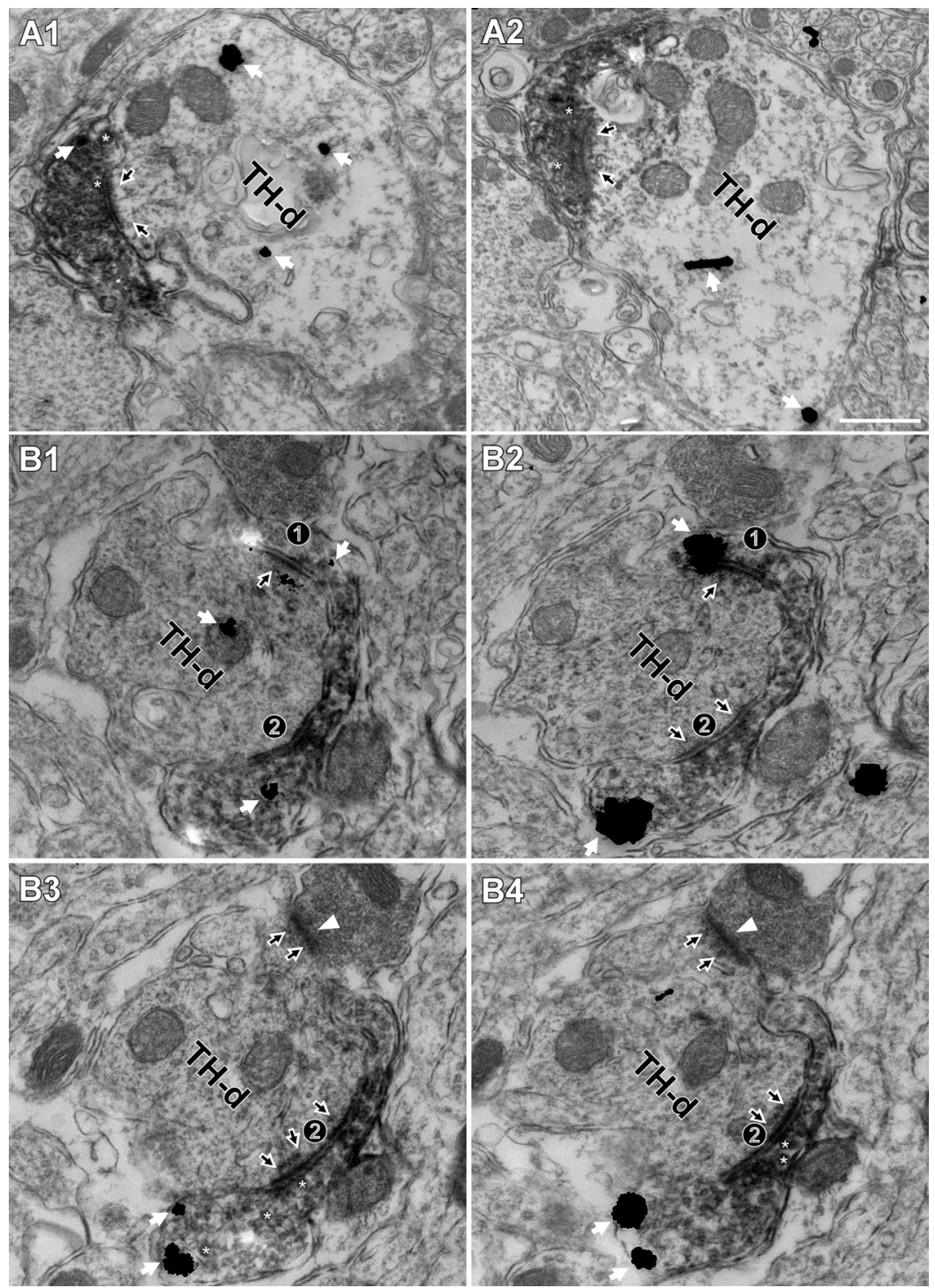

Figure 3. Ultrastructural evidence for synaptic contacts between putative C1 cells and A1/A2 catecholaminergic neurons. Electron micrographs display a number of asymmetric synapses formed between mCherry-ir terminals and catecholaminergic dendrites (TH-d) in adjacent sections. The terminal is identified by the presence of mCherry revealed by immunohistochemistry with a DAB reaction product (fine DAB precipitate) and the TH-d by black grains indicating the TH immunoreactivity revealed by a silver-gold reaction (silver-intensified immunogold particles, white arrows). The presynaptic terminal is also $\mathrm{TH}$-ir as evidenced by the presence of immunogold reaction product (white arrows). A1, A2, Labeled A1 (TH-ir) neuronal dendrite shown in serial sections contains immunogold-silver particles (white arrows) and receives an asymmetric synapse (white rimmed arrows point to postsynaptic densities) from an mCherry-ir terminal. B1-B4, Four adjacent serial sections with labeled dendritic profiles forming one conventional synaptic junction (1) and a perforated synapse (2) from labeled terminals with small round vesicles and dense core vesicles (asterisks) in the A2 catecholaminergic cell group. The perforated synapse exhibits postsynaptic densities profiles (white rimmed arrows) that have a discontinuity. Synapses were also formed between unlabeled terminals with small clear round vesicles and TH-ir dendrites (example in $\mathbf{B 3}, \mathbf{B} 4$ indicated by white arrowhead). Scale bar, $0.5 \mu \mathrm{m}$.

were virtually eliminated by blocking ionotropic glutamatergic receptors with CNQX and AP5 (Fig. 4F1,F2).

In 11 LC neurons, high-frequency stimulation voltageclamp experiments were done with cesium-filled electrodes. At $-80 \mathrm{mV} V_{\text {Hold }}$, spontaneous EPSCs were observed, and the response to $10 \mathrm{~Hz}$ trains of stimuli was identical to that recorded with potassium gluconate-filled electrodes. At $0 \mathrm{mV}$ $V_{\text {Hold }}$, however, IPSC frequency was very low and remained unchanged by the $10 \mathrm{~Hz}$ stimulus (Fig. 6A1,B). Thus, even high-frequency photostimulation of the $\mathrm{C} 1$ input did not pro- duce chloride-mediated IPSCs in LC neurons. As previously, sIPSCs had much slower decay kinetics than sEPSCs $(N=$ 18 and $N=20,44.4 \pm 4.1 \mathrm{~ms}$ vs $5.2 \pm 0.4$ ms; $p<0.0001$, Mann-Whitney test; Fig. $6 A 2)$.

\section{Optical stimulation of ChR2-expressing} RVLM-CA neurons in brain slices

Whole-cell current and voltage-clamp recordings of ChR2-eYFP-positive RVLM neurons were made in slices from adult $D \beta H^{\text {Cre/O }}$ mice to verify that these cells could be activated by light pulses. Recorded neurons (11 neurons, 5 mice) were directly visualized by the presence of eYFP fluorescence. Shortly after patching, these cells were either silent or had a slow tonic discharge pattern $(0.68 \pm 0.23 \mathrm{~Hz}, 0-2.3$ $\mathrm{Hz}, N=11)$. Each light pulse produced a depolarization leading to a single action potential $\sim 4-8 \mathrm{~ms}$ after the onset of the light pulse (Fig. $7 A, D$ ). This long delay occurred despite the fact that the lightevoked current, observed in voltageclamp, was instantaneous (Fig. 7 B1, B2). The latency to the peak of the action potential ( $5.94 \pm 0.51, N=11$ ) was the same as the latency of the EPSCs evoked in LC neurons by photostimulating the ChR2expressing axons of the RVLM CA neurons $(5.0 \pm 0.4 \mathrm{~ms}, N=23$, MannWhitney Test, NS; Fig. $7 A, C, D$ ).

All the recorded cells were filled with biocytin and, after histological processing, every recovered biocytin-positive neuron $(N=6)$ was found to contain both eYFP and tyrosine-hydroxylase immunoreactivity demonstrating that they were ChR2-expressing RVLM catecholaminergic neurons (Fig. 7E).

\section{$\mathrm{C} 1$ rather than $\mathrm{A} 1$ neurons are the most probable source of the glutamatergic PSCs recorded in the LC}

After AAV2 injection into the RVLM, $\sim 75 \%$ of the ChR2-expressing catecholaminergic neurons were $\mathrm{C} 1$ (PNMT-ir), and the remainder were A1 neurons (TH-ir but PNMT-negative; Fig. 1). To determine which catecholaminergic cells ( $\mathrm{A} 1$ or $\mathrm{C} 1$ ) were primarily responsible for the glutamatergic EPSCs elicited in LC neurons, ChR2-eYFP AAV2 was injected unilaterally (left side) into the caudal VLM, where no TH-ir neuron expresses PNMT. After 4 weeks, the LC was examined, and the proportion of eYFP-positive axonal varicosities that were also VGluT2-ir were counted in 1-3 coronal sections containing the LC per mouse. Injections resulted in eYFP-ir neuronal somata located no more rostral than $7.3 \mathrm{~mm}$ caudal to bregma, where few if any PNMT-ir neurons could be identified (Fig. 1B). For comparison, the same experiment was executed in three other mice in which the vector was injected into the RVLM and therefore predominantly 
A

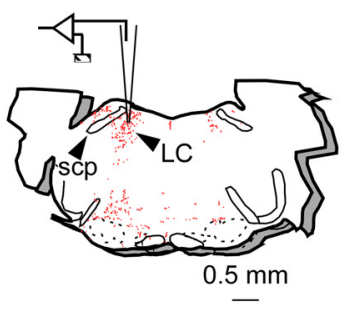

B1

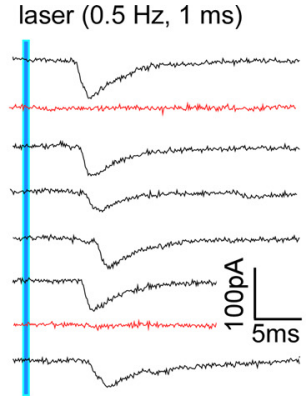

B2

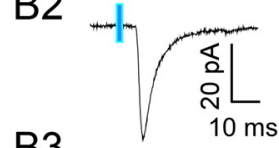

B3

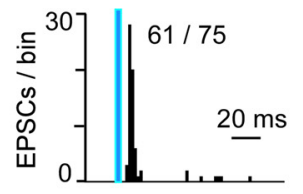

B4

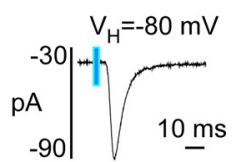

$\mathrm{V}_{\mathrm{H}}=0 \mathrm{mV}$

C1

$2 \mathrm{~Hz}$

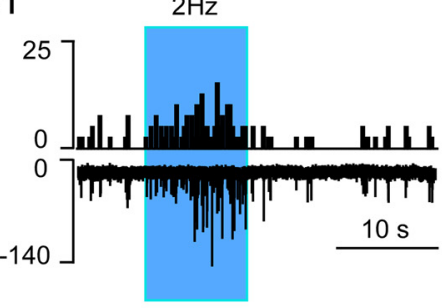

$5 \mathrm{~Hz}$

C2

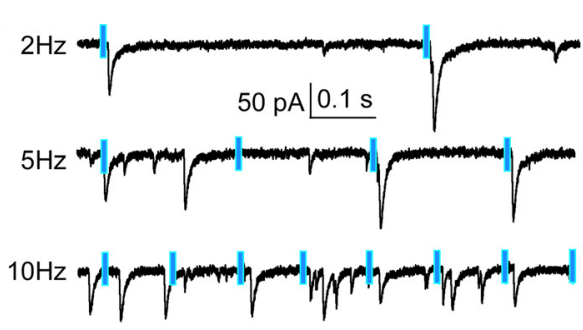

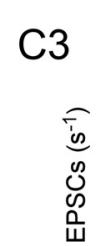

E1

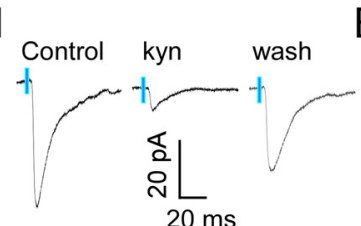

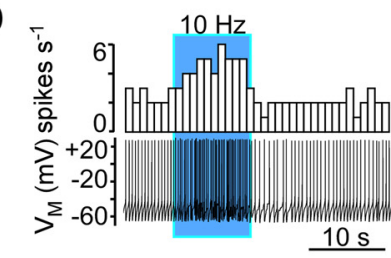

F1

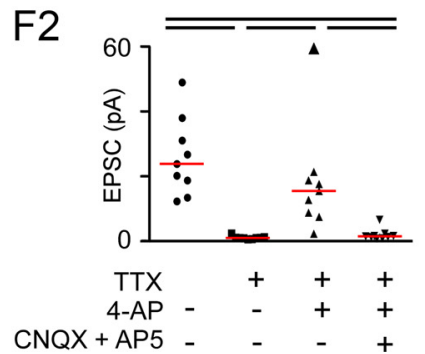

Figure 4. Monosynaptic glutamatergic input from $C 1$ neurons to $\mathrm{LC}$. $A$, Experimental design. The $\mathrm{L} C$ was identified in transverse slices by its location medial to the superior cerebellar peduncle (scp) and by the presence of a dense network of $m$ Cherry or EYFP fluorescent axons emanating from the 11 neurons (small red dots representindividual boutons originating from C1 neurons after Abbott et al., 2013). $\boldsymbol{B}$, EPSCS evoked in $\mathrm{L}$ (neurons by low-frequency photostimulation of the axons of $\mathrm{C}$ cells $(\boldsymbol{B} 1$, single responses; red traces are failures). Blue vertical line or filled box represents the period of laser stimulation throughout the figure. B2, Average of 75 consecutive stimulations. B3, Event triggered histogram showing that 61 of 75 stimuli resulted in an EPSC; $B 1-B 3$, same neuron). B4, Recording made with cesium-filled electrode at $V_{\text {Hold }}-85$ and $0 \mathrm{mV}$. Average of 75 stimuli. Note lack of outward current at $V_{\text {Hold }}=0 \mathrm{mV}$. C, responses elicited by higher frequency photostimulation of $\mathrm{C1}$ axons $(2-10 \mathrm{~Hz})$. C1, Representative example: bottom, original traces; top EPSC frequency binned every 0.5 s. C2, Expanded scale traces. Note that at 10 Hz, the evoked EPSCs are no longer synchronized with the light pulses. C3, EPSC frequency at rest, during the last $5 \mathrm{~s}$ of a $10 \mathrm{~s}, 10 \mathrm{~Hz}$ stimulation train and at three recovery times in $7 \mathrm{LC}$ neurons (red horizontal lines indicate the median response; nonparametric ANOVA, Dunn's post hoc test; group identified by an asterisk is significant from all others at $p<0.05)$. C3, Inset, Blue box represents the mean EPSC frequency (per seconds) during the stimulation period and the black boxes represent the mean EPSC frequency binned in each $1 \mathrm{~s}$ interval following the end of the stimulus. Decay time constant was $1.6 \mathrm{~s}$ with a $95 \%$ interval of $1.1-2.8 \mathrm{~s}$. D, Current-clamp recording: $10 \mathrm{~Hz}$ stimulation (1 ms pulses) more than doubles the firing rate of the neuron. $\boldsymbol{E}$, Reversible attenuation of the evoked EPSC by $1 \mathrm{~mm}$ kynurenate. $\boldsymbol{E}$, Representative example. $\boldsymbol{E 2}$, Summary data from four neurons; red horizontal lines indicate the median response, black horizontal bars at top indicate $p<0.05$ between control and kynurenate by Dunn's test following nonparametric ANOVA. $\boldsymbol{F}$, Test for monosynaptic connection. $\boldsymbol{F 1}$, Representative experiment. Each trace is the average of 75 evoked responses. F2, Group data from nine neurons/six mice; red horizontal lines indicate the median response; blackhorizontal bars at top link groups that are significantly different at $p<$ 0.05 using nonparametric ANOVA followed by Dunn's test.

labeled $\mathrm{C} 1$ cells (subset of the mice used for Fig. 1). eYFP fibers were present in the LC in both groups of animals; however, the proportion of eYFP varicosities that were also VGluT2-ir was much greater when the vector was injected into the C1 dense RVLM $(78 \% \pm 1.5 \%$;
Fig. 8, example of double-labeled terminal) than when the vector was injected into the C1 sparse caudal VLM $(10.2 \pm 1.1 \%$ doublelabeled terminals). Thus, although the A1 cells do innervate the LC, few such cells express VGluT2. This suggests that the glutamatergic 

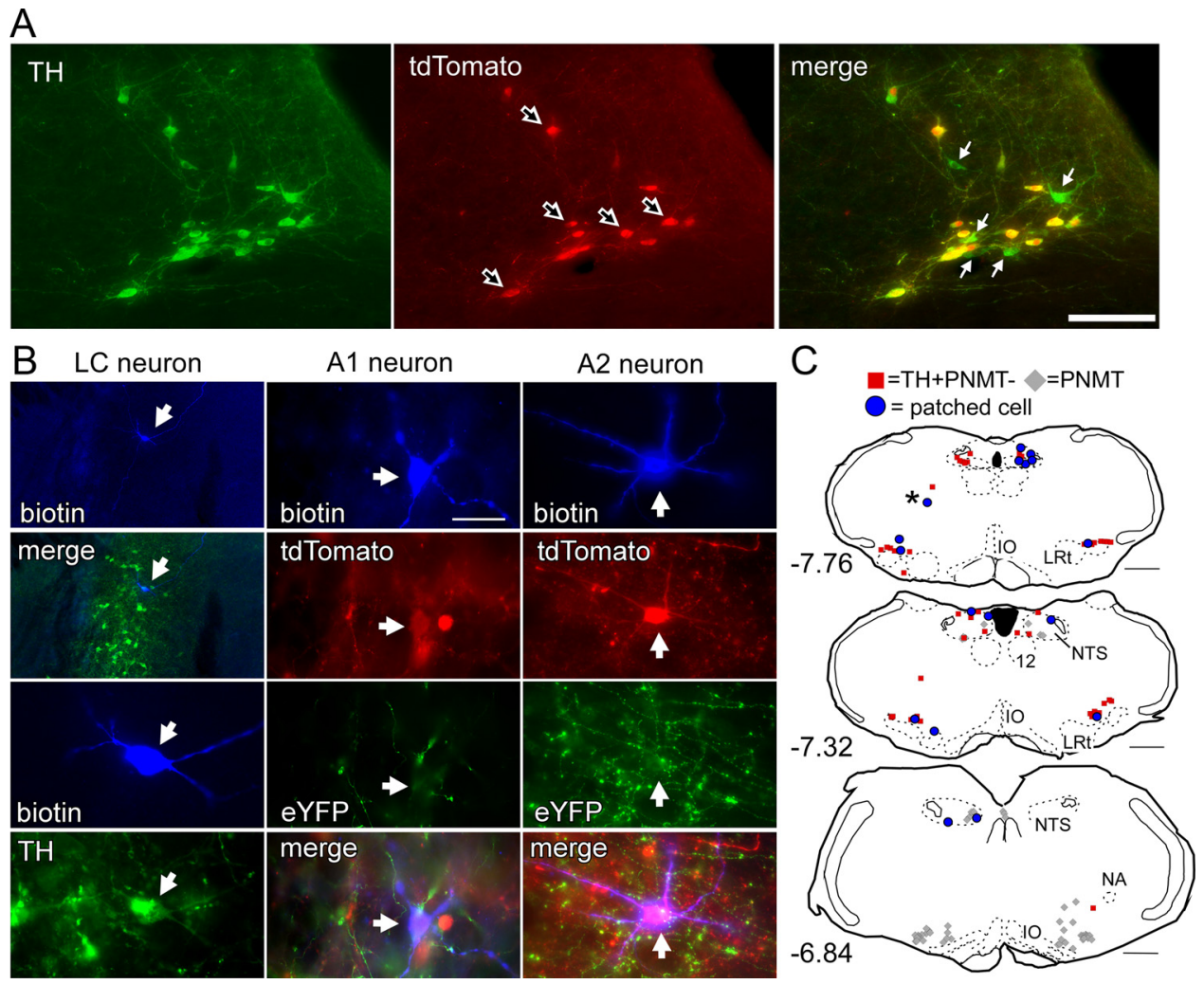

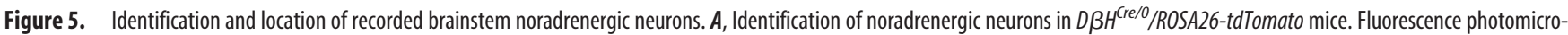
graph centered on the left dorsal vagal complex (transverse 30- $\mu \mathrm{m}$-thick section). Left, TH; Middle, tdTomato; Right, merged image. Middle, White-rimmed arrows show catecholaminergic tdTomato-labeled neurons. Right, White arrows show TH-ir neurons devoid of tdTomato fluorescence. This representative section contained 17 TH-ir neurons, 12 of which were positive for tdTomato. Some of the TH-ir neurons devoid of tdTomato could be dopaminergic. Scale bar, $100 \mu \mathrm{m}$. B, Top left, Low-power photomicrograph showing a recorded LC neuron filled with biocytin (blue) and its location in the nucleus (LC neurons identified by TH immunoreactivity, green). Bottom, Higher-magnification showing more clearly that the recorded neuron was TH-ir. $\boldsymbol{B}$, Middle, A1 neuron located in the caudal VLM, labeled with biocytin (top, blue) and identified as noradrenergic by the presence of tdTomato fluorescence (second from top, red). The neuron was surrounded by axonal processes labeled with ChR2-eYFP which originated from C1 neurons (green, third down). Bottom shows the merged image. B, Right, A2 neuron located in the nucleus of the solitary tract, filled with biocytin after recording (top, blue) and identified as noradrenergic by the presence of tdTomato fluorescence. The neuron is surrounded by axonal processes originating from $(1 \mathrm{neurons}$ (eYFP, green). Bottom, Merged image. Scale bars: $\boldsymbol{A}, 190 \mu \mathrm{m}$ in left column, $30 \mu \mathrm{m}$ in other panels; $\boldsymbol{B}, 500 \mu \mathrm{m}$. $\boldsymbol{C}$, location of the recorded noradrenergic (tdTomato-positive) A1 and A2 neurons (represented by blue-filled circles) recovered following histology plotted on representative sections that also illustrate the typical location of noradrenergic (TH + PNMT - cells represented by red squares) and adrenergic neurons (PNMT + cells represented by gray diamonds). Drawings are computer-assisted plots; numbers next to sections indicate the location of the transverse plane in relation to bregma after Paxinos and Franklin, (2004). I0, Inferior olive; LRt, lateral reticular nucleus; NA, nucleus ambiguous; NTS, nucleus of the solitary tract; 12, hypoglossal nucleus.
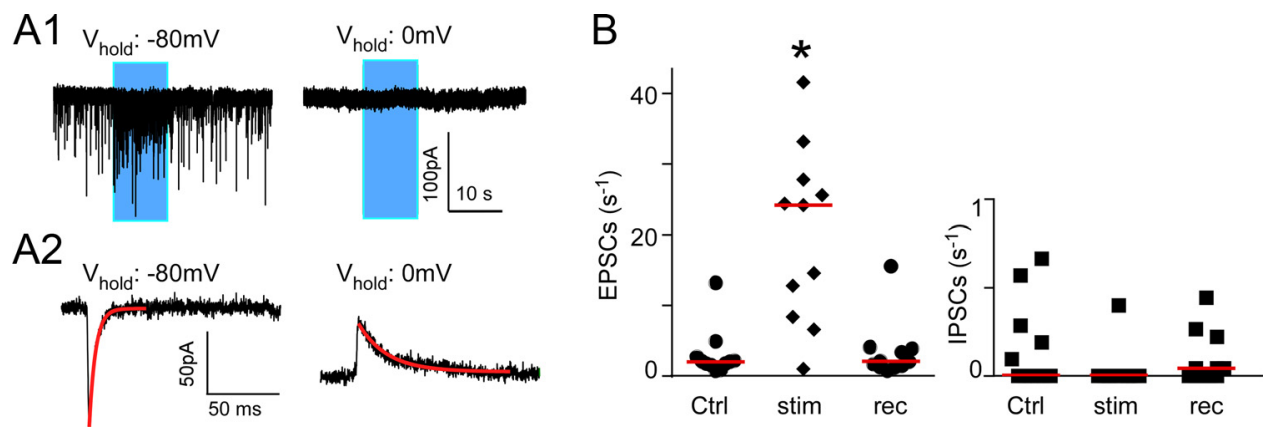

Figure 6. Photostimulation of C1 cell axons does not elicit IPSCs in LC neurons. Whole-cell recordings were obtained with cesium-filled electrodes in 11 neurons from five mice. Pulses of laser light $(1 \mathrm{~ms}, 5 \mathrm{~mW}, 10 \mathrm{~Hz}$ ) were applied for $10 \mathrm{~s}$ (blue box). $\boldsymbol{A} 1$, EPSCs were elicited when the neuron was clamped at $-80 \mathrm{mV}$ but no detectable current was elicited at $0 \mathrm{mV}$. $\mathbf{A 2}$, High-resolution example of single EPSC recorded at $-80 \mathrm{mV}$ (left) and single IPSC recorded at $0 \mathrm{mV}$ (right). The red lines are a single exponential fit of the PSC decay. EPSC decay $4.3 \mathrm{~ms}$, IPSC decay $21.2 \mathrm{~ms}$. B, Left, EPSC frequency before (Ctrl) during (stim) and after photostimulation at $10 \mathrm{~Hz}$ (rec). Red horizontal lines indicate the median response in both graphs. Asterisk indicates $p<0.05$ relative to the control and recovery period (nonparametric ANOVA, Dunn's post hoc test). B, Right, IPSCs were very infrequent and their frequency was unaffected by photostimulation.

EPSCs elicited in LC neurons by photostimulation of axons from the catecholaminergic neurons located in the RVLM were most likely caused by activation of $\mathrm{C} 1$ cells. This interpretation assumes that the A1 neurons located in the RVLM have the same phenotype as those located in the caudal VLM.
Photostimulation of RVLM-CA neurons activates A1 and A2 neurons in slices

To visualize $\mathrm{A} 1$ and $\mathrm{A} 2$ neurons in live slices, we used adult $D \beta H^{\text {Cre/o } / R O S A 26-t d T o m a t o ~ m i c e . ~ P r e l i m i n a r y ~ h i s t o l o g i c a l ~}$ experiments performed in three such mice showed that tdTo- 
mato was expressed by $\mathrm{TH}$-ir neurons ( $94 \pm 1 \%$ in the A1 region of the VLM, $92 \pm 1 \%$ in the nucleus of the solitary tract, i.e., A2/C2 region; Fig. 5A). Neurons immunoreactive for $\mathrm{tdTomato}$ and $\mathrm{TH}$ lacked PNMT in regions caudal to the rostral pole of the lateral reticular nucleus (Fig. 5C). Therefore, we targeted this region to record $\mathrm{A} 1$ neurons (location of biocytin-filled recorded neurons also shown in Fig. 5C). In the dorsal medulla, neurons immunoreactive for both tdTomato and TH lacked PNMT in regions caudal to the area postrema. These cells were therefore A2 neurons. We recorded preferentially from tdTomato-positive neurons located in this caudal region but a fraction of the recorded neurons could have been PNMT-ir C2 neurons (Fig. 5C). TdTomato was detected in $86 \pm 1 \%$ of A1 and $66 \pm 13 \%$ of A2 neurons, therefore the sampled neurons may not have been totally representative of this population of neurons.

For slice recordings, we injected DIO ChR2-eYFP AAV2 (8 mice) or DIO ChR2mCherry AAV2 (4 mice) into the $\mathrm{C} 1$ region of $D \beta H^{C r e / 0} /$ ROSA26-tdTomato mice (6 males, 6 females). Five to 14 weeks later, 15 tdTomato-labeled A1 and 21 tdTomatolabeled A2 neurons were recorded in transverse medulla oblongata slices. Cells that received monosynaptic input from $\mathrm{C} 1$ neurons were filled with biocytin and processed histologically. We verified that the recorded neurons contained tdTomato and plotted the location of the recorded neurons (Fig. $5 C$ ). In some cases, the catecholaminergic nature of the recorded neurons was also verified by the presence of TH immunoreactivity in addition to the presence of tdTomato in the biocytin-labeled neuron (6 A1 neurons, 13 A2 neurons).

Low-frequency photostimulation ( $1 \mathrm{~ms}, 5 \mathrm{~mW}, 0.5 \mathrm{~Hz})$ elicited EPSCs in 60\% (9/14) of A1 neurons sampled with a $36.3 \pm$ $11.7 \%$ failure rate. Average EPSC amplitude (including failures) was $24.6 \pm 10.5 \mathrm{pA}$. As in the LC, the EPSCs were virtually eliminated by the addition of TTX $(N=5$ neurons; Fig. $9 A 1, A 2)$, were reinstated after addition of $4-\mathrm{AP}$, and were again eliminated in the presence of CNQX and AP-5 (Fig. 9A1,A2). Responses of the same five A1 neurons to a high-frequency photostimulation (1 $\mathrm{ms}, 5 \mathrm{~mW}, 10 \mathrm{~Hz}, 10 \mathrm{~s}$ train), applied in alternation with the periods of low-frequency stimulation, were also examined. The $10 \mathrm{~Hz}$ trains produced the same pattern of response as in the LC (compare Figs. 4C1 and 9B1), namely an increase in EPSC frequency that reached a steady-state within $5 \mathrm{~s}$. As in the LC, the EPSCs elicited by high-frequency stimulation were largely random relative to the light pulses (not shown), and their steadystate frequency was several-fold higher than the stimulus frequency (2.5-fold in Fig. 9B1; range: 1.1- to 3.8-fold, median 2.8 -fold; $N=4$ ). TTX reduced but did not eliminate the EPSCs evoked by high-frequency stimulation (Fig. 9B1,B2), although EPSC frequency rose more slowly during the photostimulation than in control. Adding 4-AP increased the frequency of EPSCs evoked by the stimulus and changed the temporal pattern of response (Fig. 9B1,B2) such that the maximal EPSC frequency was
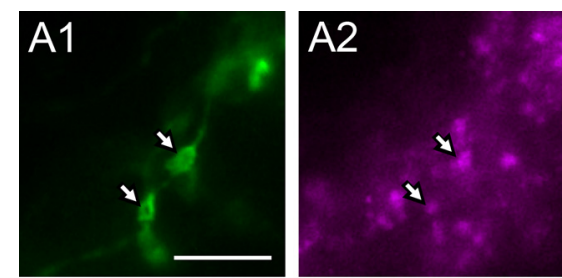

$\mathrm{B}_{1}$
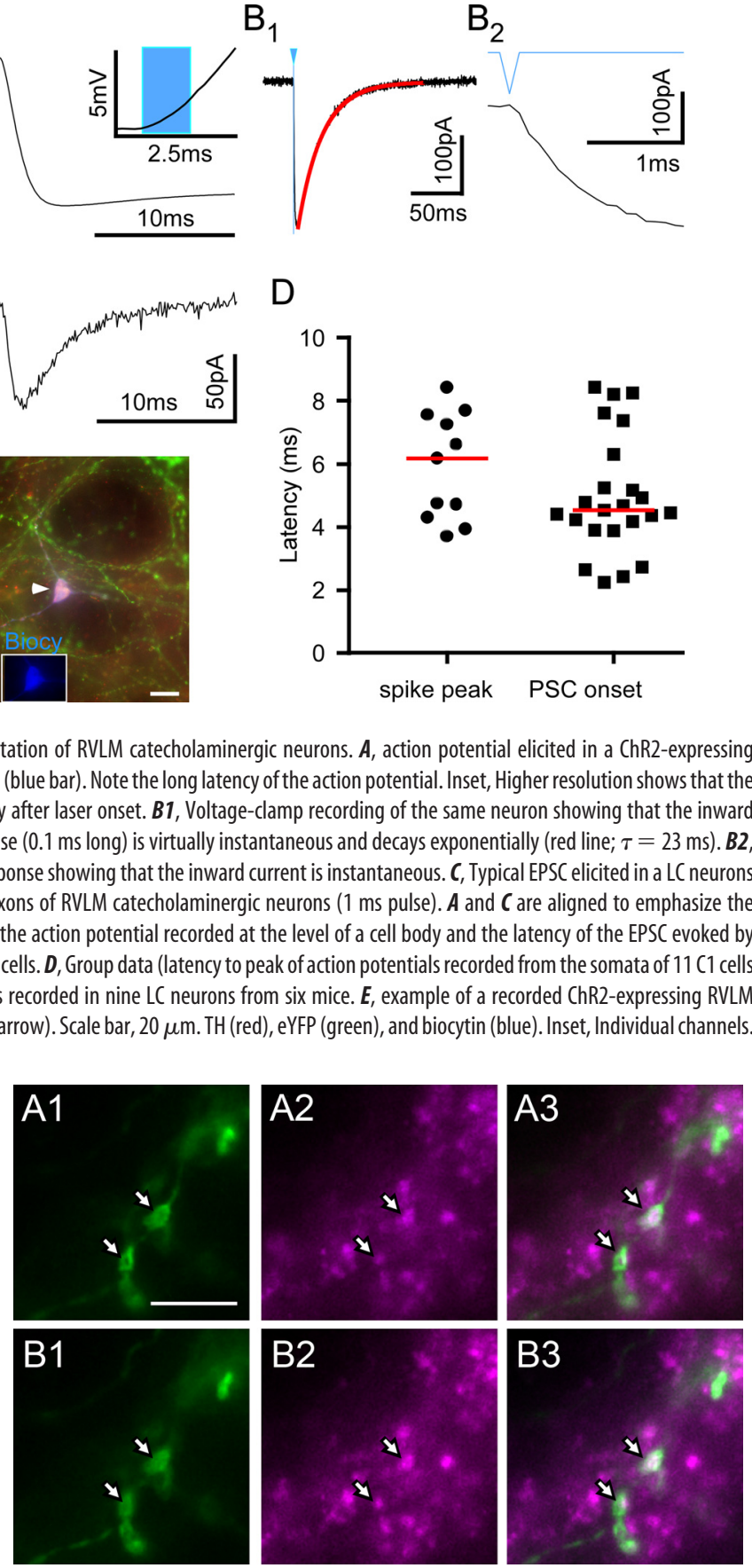

Figure 8. Terminals from RVLM catecholaminergic neurons in locus coeruleus are glutamatergic. $A, B$, Serial $0.3 \mu \mathrm{m} Z$-stack sections of axonal varicosities from RVLM catecholaminergic neurons. A1, B1, eYFP immunoreactivity (green); $\mathbf{A 2}$, B2, VGluT2 (magenta); $\mathbf{A 3}, \boldsymbol{B} 3$, merged image. Scale bar, $5 \mu \mathrm{m}$.

elicited at the onset of the stimulus train and tended to decay thereafter. Following addition of CNQX and AP5, all observable PSCs were eliminated and the stimulus train produced no observable current (Fig. 9B1,B2).

Similar results were obtained with photostimulation of $\mathrm{C} 1$ terminals onto the A2 neurons. Low-frequency photostimulation ( 0.5 $\mathrm{Hz}$ ) elicited EPSCs in 57\% (12/21) of A2 cells sampled (amplitude $22.86 \pm 5.9 \mathrm{pA}$ ) with occasional failures (failure rate, $27.5 \pm 8.8 \%$; $n=8)$. The EPSCs were eliminated by the addition of tetrodotoxin, reinstated by addition of 4-AP, and again abolished after addition of CNQX and AP-5 ( $N=8$; Fig. 10A1,A2). The responses of A2 neu- 
A1

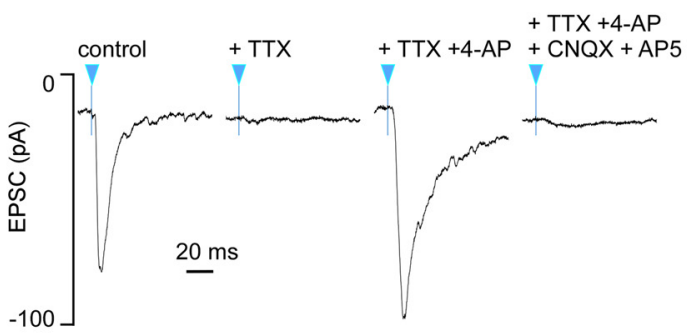

B1

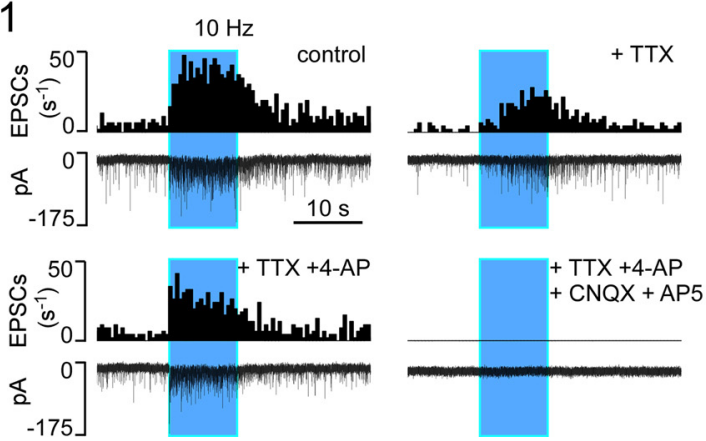

A2

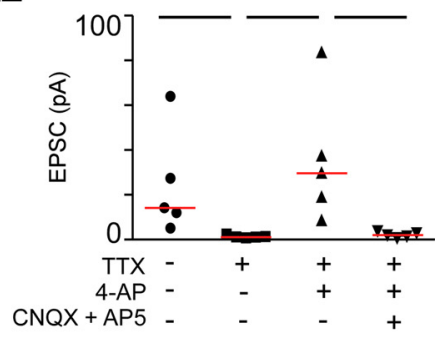

B2

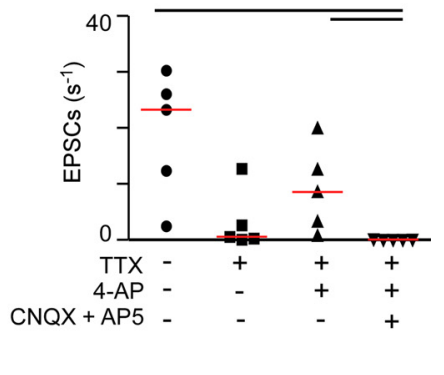

Figure 9. A1 neurons receive monosynaptic glutamatergic input from C1 neurons. A, Effect of TTX, 4-AP and glutamate receptor antagonists on the EPSCS elicited by low-frequency (0.5 Hz) photostimulation of the axons of RVLM catecholaminergic neurons. A1, Representative example; $0.5 \mathrm{~Hz}, 1 \mathrm{~ms}$ photostimulation at blue arrows, each trace is the average of 75 stimuli. $\mathbf{A 2}$, Group data from five neurons and four mice. Red horizontal lines indicate the median response; black horizontal bars at top of figure link groups that are significantly different at $p<0.05$ determined using a nonparametric ANOVA with Dunn's post hoc test. B, Effect of TTX, 4-AP and glutamate receptor antagonists on the responses elicited by high-frequency photostimulation (10 Hz, $1 \mathrm{~ms}$ pulses; photostimulation periods represented by the blue boxes). $\boldsymbol{B} 1$, Representative example; bottom traces, original recordings, $V_{\text {Hold }}-85 \mathrm{mV}$. B2, Group data; red horizontal lines indicate the median response; black horizontal bars at top of figure link groups that are significantly different at $p<0.05$ determined using a nonparametric ANOVA with Dunn's post hoc test.

\section{A1}

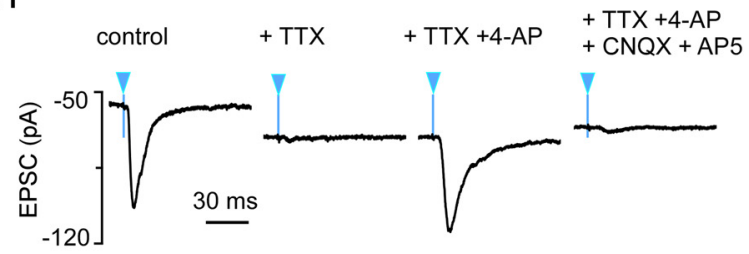

B1

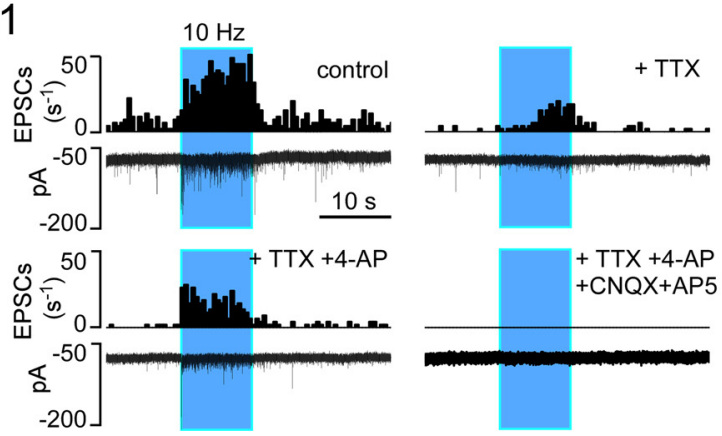

A2

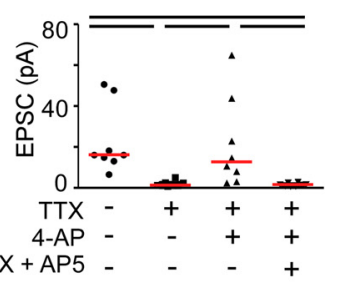

B2

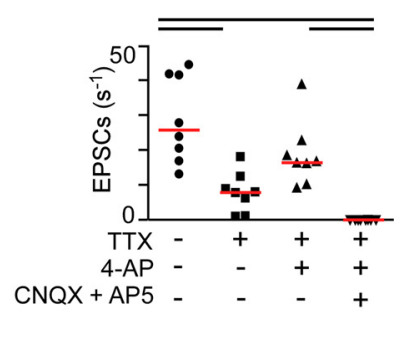

Figure 10. A2 neurons receive monosynaptic glutamatergic input from C 1 neurons. $A$, effect of TTX, 4-AP and glutamate receptor antagonists on the EPSCs elicited by low-frequency (0.5 Hz) photostimulation of the axons of RVLM catecholaminergic neurons. $\boldsymbol{A}$, representative example; $0.5 \mathrm{~Hz}, 1 \mathrm{~ms}$ photostimulation at blue arrows, each trace is the average of 75 stimuli. $\boldsymbol{A 2}$, Group data from eight neurons and seven mice; red horizontal lines represent the median response; black horizontal bars at top of figure link groups that are significantly different at $p<0.05$ determined using a nonparametric ANOVA with Dunn's post hoc test. $\boldsymbol{B}$, effect of TTX, 4-AP and glutamate receptor antagonists on the responses elicited by high-frequency photostimulation of the axons of RVLM catecholaminergic neurons $\left(10 \mathrm{~Hz}, 1 \mathrm{~ms}\right.$ pulses; photostimulation period represented by the blue boxes). $\boldsymbol{B} 1$, Representative example; bottom traces, original recordings, $V_{\text {Hold }}-85 \mathrm{mV}$. $\boldsymbol{B 2}$, Group data; red horizontal lines represent the median response; black horizontal bars at top of figure link groups that are significantly different at $p<0.05$ determined using a nonparametric ANOVA with Dunn's post hoc test.

rons to $10 \mathrm{~Hz}, 10 \mathrm{~s}$ trains of $1 \mathrm{~ms}$ laser pulses were identical to those observed in A1 neurons. The high-frequency stimulus produced a gradual increase in PSC frequency that reached steady state within $3 \mathrm{~s}$ and were largely random with respect to the light stimuli (not shown). The steady-state frequency of the evoked EPSCs was several fold higher than the stimulus frequency (4.5-fold in Fig. 10B1; range, 1.7- to 5.7-fold, median 3.4-fold, $N=8$ ). TTX again reduced but did not eliminate the EPSCs (Fig. 10B1,B2), which were increased after 


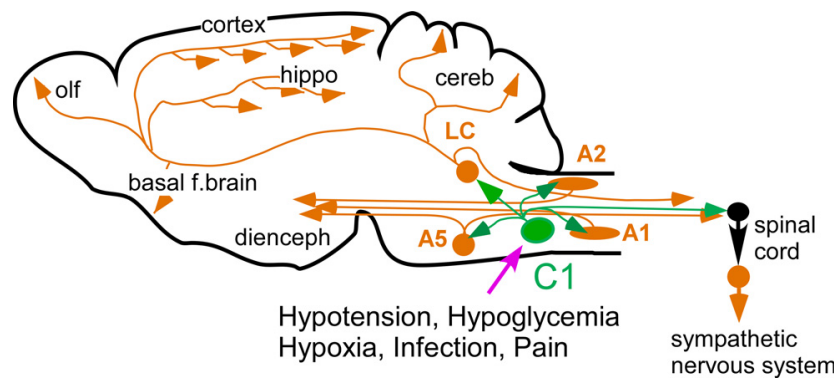

Figure 11. The C1 cells regulate peripheral and CNS noradrenaline release. C1 cells (green) directly innervate and activate sympathetic preganglionic neurons (black) plus every major group of CNS noradrenergic neurons (orange). The C1 cells thus have the capacity to activate noradrenergic release throughout the body and the brain under conditions such as, hypotension, hypoxia, etc. Basal f. brain, Basal forebrain; cereb, cerebellum; dienceph, diencephalon; hippo, hippocampus; olf, olfactory bulb.

addition of 4-AP and underwent a similar temporal change as described by A1 cells (Fig. 10B1,B2). The addition of CNQX eliminated all observable EPSCs before and during the photostimulus (Fig. 10B1,B2).

One catecholaminergic neuron, not included in the above description, was recorded in the intermediate reticular nucleus (Fig. $8 C$, asterisk), and therefore could not be classified as either A1 or A2. C1 axon photostimulation also elicited monosynaptic, glutamatergic EPSCs in this neuron.

\section{Discussion}

We show that RVLM catecholaminergic neurons, most likely $\mathrm{C} 1$ neurons, establish glutamatergic synapses with LC, A1 and A2 noradrenergic neurons. The $\mathrm{C} 1$ neurons activate the sympathetic nervous system in response to hypoglycemia, hypotension, pain, hypoxia, infection, and psychological stress (Ericsson et al., 1994; Jansen et al., 1995; Guyenet, 2006, 2013; Marina et al., 2011; Abbott et al., 2012). The C1 cells presumably also broadly increase CNS noradrenaline release under the same conditions (summarized in Fig. 11).

\section{Glutamatergic activation of lower brainstem noradrenergic neurons by the $\mathrm{C} 1$ cells}

After AAV injection into the RVLM, ChR2 was almost exclusively expressed by catecholaminergic neurons, $75 \%$ of which were $\mathrm{TH}-$ and PNMT-ir, thus C1 (Hokfelt et al., 1974). A similar proportion of ChR2-labeled axonal varicosities (78\%) were VGluT2-ir whereas caudal VLM catecholaminergic neurons (A1 cells) had generally VGluT2-negative varicosities. Accordingly, C1 rather than A1 neurons were the principal source of the glutamatergic EPSCs observed presently. However, we confirm that A1 neurons also innervate the LC (Robertson et al., 2013) and find that $~ 10 \%$ of these cells may also express VGluT2 (Stornetta et al., 2002a). A subset of A1 cells may therefore be glutamatergic and may have contributed to the observed glutamatergic EPSCs along with $\mathrm{C} 1$ cells. Approximately $10 \%$ of $\mathrm{C} 1$ cells express the noradrenaline transporter, representing yet another example of a potential A1/C1 intermediate phenotype (Lorang et al., 1994; Comer et al., 1998).

C1 axon stimulation elicited EPSCs in a majority of LC (53\%) and other noradrenergic neurons sampled (62\%). These percentages could be underestimated because the number of ChR2expressing varied between animals, as did the level of expression of ChR2.
The test used to determine whether the EPSCs evoked by $\mathrm{C} 1$ cell stimulation were monosynaptic was based on the effects of TTX and 4-AP (Petreanu et al., 2009). When short light pulses are used, ChR2-induced depolarization, hence calcium influx and vesicular release, is critically dependent on voltage-gated sodium current, and therefore blocked by TTX (Boyden et al., 2005; Zhang and Oertner, 2007; Petreanu et al., 2009). Addition of 4-AP reinstates transmitter release by facilitating the depolarization of the stimulated nerve terminals (Petreanu et al., 2009). The long EPSC latency observed without TTX $(\sim 5 \mathrm{~ms})$ almost certainly reflects the gradual depolarizing action of $\mathrm{ChR} 2$, not the conduction velocity of the stimulated fibers. Indeed, ChR2generated action potentials elicited by direct somatic illumination, antidromic axonal stimulation or monosynaptic transmission have very similar latencies in tissue slices although the inward current generated in ChR2-expressing cells is instantaneous (Petreanu et al., 2007, 2009; Zhang and Oertner, 2007). We verified that these assumptions apply to the $\mathrm{C} 1$ cells by showing that the latency to produce a spike in ChR2-expressing C1 somata was identical to the EPSC latency observed in the noradrenergic neurons by photostimulating the axons of the C1 cells. Under TTX and 4-AP, the latency of the EPSCs was longer still, likely reflecting that when fast sodium channels are inoperative, sufficient terminal depolarization to produce calcium influx is principally dependent on ChR2 and is delayed. In sum, the observed latencies were fully compatible with monosynaptic transmission.

The EPSCs elicited by stimulating $\mathrm{C} 1$ axons at $10 \mathrm{~Hz}$ had a frequency higher than the light pulses and tended to occur randomly. This characteristic likely indicates the gradual accumulation of intracellular calcium within the photostimulated axons rather than some form of polysynaptic transmission. Because of the relatively slow kinetics of ChR2(H134R), high-frequency stimulation produces a tonic depolarization. Cytoplasmic calcium rise probably also accounted for the brief persistence of EPSCs after a high-frequency photostimulus in the presence of TTX (Figs. 9B1, 10B1). The fact that asynchronous EPSCs could be elicited in the presence of TTX, albeit after a longer delay than without TTX (Figs. 9B1, 10B1) also suggests that they could be mediated by a presynaptic rise in intracellular calcium rather than by some form of polysynaptic transmission.

The EPSCs elicited by low or high-frequency stimulation in the presence of TTX and 4-AP were virtually eliminated by standard ionotropic glutamatergic receptor antagonists demonstrating their predominantly glutamatergic nature. This result agrees with the fact that ChR2-labeled catecholaminergic varicosities were VGluT2-ir and formed conventional excitatory-like synapses with the brainstem noradrenergic neurons examined. Neither C1 nor A1 cells express GABAergic or glycinergic markers (Comer et al., 1999; Schreihofer et al., 1999; Stornetta and Guyenet, 1999; Stornetta et al., 2002a). In agreement, IPSCs were never evoked by $\mathrm{C} 1$ axon stimulation, even at high-frequency. Rat LC neurons may receive input from nearby GABA interneurons (Aston-Jones et al., 2004) but these interneurons are probably not targeted by $\mathrm{C} 1$ cells because $\mathrm{C} 1$ cell stimulation did not produce IPSCs in LC neurons.

Electrical stimulation of the RVLM produces a biphasic response in LC neurons in vivo (excitation-inhibition; Aston-Jones et al., 1992). The excitation was originally attributed to a noncatecholaminergic input and the inhibition supposedly due to $\mathrm{C} 1$ neurons. When rat ChR2-expressing RVLM catecholaminergic cells are selectively photoactivated in vivo, the LC response also consists of an excitation-inhibition sequence but both components are eliminated by the administration of a glutamate antag- 
onist (Abbott et al., 2012). The inhibition could therefore be a polysynaptic effect or an intrinsic property of LC neurons. It could also result from catecholamine release by LC dendrites or by the A1 input to the LC (Egan et al., 1983; Williams et al., 1984; Huang et al., 2012).

In summary, the EPSCs evoked in LC, $\mathrm{A} 1$ and $\mathrm{A} 2$ neurons by photostimulating RVLM catecholaminergic neurons were glutamatergic, monosynaptic, and most probably originated from $\mathrm{C} 1$ rather than A1 cells. The electrophysiological evidence is consistent with the presence of VGluT2 in the terminals of RVLM catecholaminergic neurons and with ultrastructural evidence for synapses between these neurons and lower brainstem noradrenergic neurons.

\section{Is the glutamatergic phenotype of the $\mathrm{C} 1$ cells an artifact caused by AAV2 transfection?}

VGluT2 is downregulated postnatally in most CNS dopaminergic neurons and upregulated when dopaminergic neurons are lesioned or maintained in culture (Dal et al., 2008; Bérubé-Carrière et al., 2009; El Mestikawy et al., 2011). Exposure to AAV2 may reinstate VGluT2 expression in mature dopaminergic neurons (for review, see El Mestikawy et al., 2011). However, in adult rats never exposed to AAV, most C1 neurons express VGLUT2mRNA and VGluT2 immunoreactivity is detectable in most PNMTimmunoreactive varicosities. In addition, in $\mathrm{TH}$-Cre rats, the AAV2 vector used presently does not change the VGluT2 immunoreactivity present in $\mathrm{C} 1$ neuron axonal varicosities (Stornetta et al., 2002a; DePuy et al., 2013). For technical reasons we could not replicate this evidence in mice. However, unless VGluT2 upregulation by AAV2 vectors is unique to the mouse and unless, among VLM catecholaminergic neurons it is unique to the RVLM, the glutamatergic component of $\mathrm{C} 1$ cell transmission observed in the present study is not an AAV-induced artifact.

\section{Do the $\mathrm{C} 1$ cells release catecholamines?}

The $\mathrm{C} 1$ cells express vesicular monoamine transporter-2 (Sevigny et al., 2008). They also synthesize numerous neuropeptides (for review, see Guyenet et al., 2013) and their terminals contain dense-core vesicles likely mediating the release of these substances (present data). Our failure to detect any residual synaptic event after glutamate receptor blockade, even during highfrequency stimulation, is consistent with our prior study on vagal motor neurons (DePuy et al., 2013) and likely means that our tests were not suited to detect responses mediated by peptides and catecholamines. In subcortical regions, noradrenaline often produces long-term potentiation or even metaplasticity (Neverova et al., 2007; Inoue et al., 2013). These phenomena develop over a much longer time period than the acute responses that we examined. Finally, the catecholamines released by the $\mathrm{C} 1$ cells could have limited effects on neurons and instead activate glia (O’Donnell et al., 2012).

\section{Control of CNS noradrenergic neurons by the $\mathrm{C} 1$ cells: functional significance}

The $\mathrm{C} 1$ cells are activated by hypoglycemia, hypotension, hypercapnia, infection, hypoxia, and pain, and contribute to the increased sympathetic tone and corticosterone release elicited by these stimuli (Madden and Sved, 2003; Abbott et al., 2009; Marina et al., 2011; Guyenet et al., 2013). These stimuli also activate LC neurons (Elam et al., 1981; Morilak et al., 1987a,b; Curtis et al., 1993; Murase et al., 1994; Guyenet et al., 2013). The present results suggest that the $\mathrm{C} 1$ cells likely relay these stimuli to LC, A1 and A2 noradrenergic neurons as well as to sympathetic pregan- glionic neurons (Fig. 11). The A5 neurons, not examined in the present study, are excited by $\mathrm{C} 1$ neurons in vivo and are probably also directly innervated by these cells (Card et al., 2006; Abbott et al., 2012, 2013).

$\mathrm{C} 1$ cell activation by hypotension or by any of the abovementioned stresses is therefore likely to produce widespread increases of CNS noradrenaline release with broad consequences on neuronal excitability, glial cell metabolism, and potentially, cerebral blood flow (Bekar et al., 2008; Attwell et al., 2010; Gordon et al., 2011).

\section{References}

Abbott SB, Stornetta RL, Socolovsky CS, West GH, Guyenet PG (2009) Photostimulation of channelrhodopsin-2 expressing ventrolateral medullary neurons increases sympathetic nerve activity and blood pressure in rats. J Physiol 587:5613-5631. CrossRef Medline

Abbott SB, Kanbar R, Bochorishvili G, Coates MB, Stornetta RL, Guyenet PG (2012) C1 neurons excite locus coeruleus and A5 noradrenergic neurons along with sympathetic outflow in rats. J Physiol 590:2897-2915. CrossRef Medline

Abbott SB, DePuy SD, Nguyen T, Coates MB, Stornetta RL, Guyenet PG (2013) Selective optogenetic activation of rostral ventrolateral medullary catecholaminergic neurons produces cardiorespiratory stimulation in conscious mice. J Neurosci 33:3164-3177. CrossRef Medline

Appleyard SM, Marks D, Kobayashi K, Okano H, Low MJ, Andresen MC (2007) Visceral afferents directly activate catecholamine neurons in the solitary tract nucleus. J Neurosci 27:13292-13302. CrossRef Medline

Aston-Jones G, Cohen JD (2005) An integrative theory of locus coeruleusnorepinephrine function: adaptive gain and optimal performance. Annu Rev Neurosci 28:403-450. CrossRef Medline

Aston-Jones G, Astier B, Ennis M (1992) Inhibition of noradrenergic locus coeruleus neurons by $\mathrm{C} 1$ adrenergic cells in the rostral ventral medulla. Neurosci 48:371-382. CrossRef

Aston-Jones G, Zhu Y, Card JP (2004) Numerous GABAergic afferents to locus ceruleus in the pericerulear dendritic zone: possible interneuronal pool. J Neurosci 24:2313-2321. CrossRef Medline

Atasoy D, Aponte Y, Su HH, Sternson SM (2008) A FLEX switch targets Channelrhodopsin-2 to multiple cell types for imaging and long-range circuit mapping. J Neurosci 28:7025-7030. CrossRef Medline

Attwell D, Buchan AM, Charpak S, Lauritzen M, Macvicar BA, Newman EA (2010) Glial and neuronal control of brain blood flow. Nature 468:232243. CrossRef Medline

Bekar LK, He W, Nedergaard M (2008) Locus coeruleus alpha-adrenergicmediated activation of cortical astrocytes in vivo. Cereb Cortex 18:27892795. CrossRef Medline

Berridge CW, Schmeichel BE, España RA (2012) Noradrenergic modulation of wakefulness/arousal. Sleep Med Rev 16:187-197. CrossRef Medline

Bérubé-Carrière N, Riad M, Dal BG, Lévesque D, Trudeau LE, Descarries L (2009) The dual dopamine-glutamate phenotype of growing mesencephalic neurons regresses in mature rat brain. J Comp Neurol 517:873891. CrossRef Medline

Bochorishvili G, Stornetta RL, Coates MB, Guyenet PG (2012) PreBötzinger complex receives glutamatergic innervation from galaninergic and other retrotrapezoid nucleus neurons. J Comp Neurol 520:10471061. CrossRef Medline

Bohn MC, Dreyfus CF, Friedman WJ, Markey KA (1987) Glucocorticoid effects on phenylethanolamine $N$-methyltransferase (PNMT) in explants of embryonic rat medulla oblongata. Brain Res 465:257-266. Medline

Boyden ES, Zhang F, Bamberg E, Nagel G, Deisseroth K (2005) Millisecondtimescale, genetically targeted optical control of neural activity. Nat Neurosci 8:1263-1268. CrossRef Medline

Bruinstroop E, Cano G, Vanderhorst VG, Cavalcante JC, Wirth J, SenaEsteves M, Saper CB (2012) Spinal projections of the A5, A6 (locus coeruleus), and A7 noradrenergic cell groups in rats. J Comp Neurol 520: 1985-2001. CrossRef Medline

Byrum CE, Guyenet PG (1987) Afferent and efferent connections of the A5 noradrenergic cell group in the rat. J Comp Neurol 261:529-542. CrossRef Medline

Card JP, Sved JC, Craig B, Raizada M, Vazquez J, Sved AF (2006) Efferent projections of rat rostroventrolateral medulla $\mathrm{Cl}$ catecholamine neurons: 
implications for the central control of cardiovascular regulation. J Comp Neurol 499:840-859. CrossRef Medline

Carter ME, Yizhar O, Chikahisa S, Nguyen H, Adamantidis A, Nishino S, Deisseroth K, de Lecea L (2010) Tuning arousal with optogenetic modulation of locus coeruleus neurons. Nat Neurosci 13:1526-1533. CrossRef Medline

Comer AM, Qi J, Christie DL, Gibbons HM, Lipski J (1998) Noradrenaline transporter expression in the pons and medulla oblongata of the rat: localisation to noradreneric and some $\mathrm{Cl}$ adrenergic neurones. Mol Brain Res 62:65-76. CrossRef Medline

Comer AM, Gibbons HM, Qi J, Kawai Y, Win J, Lipski J (1999) Detection of mRNA species in bulbospinal neurons isolated from the rostral ventrolateral medulla using single-cell RT-PCR. Brain Res Brain Res Protoc 4:367-377. CrossRef Medline

Corson JA, Erisir A (2013) Monosynaptic convergence of chorda tympani and glossopharyngeal afferents onto ascending relay neurons in the nucleus of the solitary tract: a high-resolution confocal and correlative electron microscopy approach. J Comp Neurol 521:2907-2926. CrossRef Medline

Curtis AL, Drolet G, Valentino RJ (1993) Hemodynamic stress activates locus coeruleus neurons of unanesthetized rats. Brain Res Bull 31:737744. CrossRef Medline

Dahlstrom A, Fuxe K (1964) Demonstration of monoamines in the cell bodies of brain stem neurons. Acta Physiol Scand 62:1-55.

Dal BG, Bérubé-Carrière N, Mendez JA, Leo D, Riad M, Descarries L, Lévesque D, Trudeau LE (2008) Enhanced glutamatergic phenotype of mesencephalic dopamine neurons after neonatal 6-hydroxydopamine lesion. Neuroscience 156:59-70. CrossRef Medline

DePuy SD, Stornetta RL, Bochorishvili G, Deisseroth K, Witten I, Coates M, Guyenet PG (2013) Glutamatergic neurotransmission between the C1 neurons and the parasympathetic preganglionic neurons of the dorsal motor nucleus of the vagus. J Neurosci 33:1486-1497. CrossRef Medline

Egan TM, Henderson G, North RA, Williams JT (1983) Noradrenalinemediated synaptic inhibition in rat locus coeruleus neurones. J Physiol 345:477-488. Medline

Elam M, Yao T, Thorén P, Svensson TH (1981) Hypercapnia and hypoxia: chemoreceptor-mediated control of locus coeruleus neurons and splanchnic sympathetic nerve. Brain Res 222:373-381. CrossRef Medline

Elam M, Yao T, Svensson TH, Thoren P (1984) Regulation of locus coeruleus neurons and splanchnic, sympathetic nerves by cardiovascular afferents. Brain Res 290:281-287. CrossRef Medline

El Mestikawy S, Wallén-Mackenzie A, Fortin GM, Descarries L, Trudeau LE (2011) From glutamate co-release to vesicular synergy: vesicular glutamate transporters. Nat Rev Neurosci 12:204-216. CrossRef Medline

Erickson JT, Millhorn DE (1994) Hypoxia and electrical stimulation of the carotid sinus nerve induce c-Fos-like immunoreactivity within catecholaminergic and serotinergic neurons of the rat brainstem. J Comp Neurol 348:161-182. CrossRef Medline

Ericsson A, Kovács KJ, Sawchenko PE (1994) A functional anatomical analysis of central pathways subserving the effects of interleukin-1 on stressrelated neuroendocrine neurons. J Neurosci 14:897-913. Medline

Fenik VB, Rukhadze I, Kubin L (2008) Inhibition of pontine noradrenergic A7 cells reduces hypoglossal nerve activity in rats. Neuroscience 157:473482. CrossRef Medline

Gordon GR, Howarth C, MacVicar BA (2011) Bidirectional control of arteriole diameter by astrocytes. Exp Physiol 96:393-399. CrossRef Medline

Grossman N, Simiaki V, Martinet C, Toumazou C, Schultz SR, Nikolic K (2013) The spatial pattern of light determines the kinetics and modulates backpropagation of optogenetic action potentials. J Comput Neurosci 34:477-488. CrossRef Medline

Guyenet PG (2006) The sympathetic control of blood pressure. Nat Rev Neurosci 7:335-346. CrossRef Medline

Guyenet PG, Stornetta RL, Bochorishvili G, Depuy SD, Burke PG, Abbott SB (2013) Invited review EB 2012: C1 neurons: the body's EMTs. Am J Physiol Regul Integr Comp Physiol 305:R187-204. CrossRef Medline

Haxhiu MA, Yung K, Erokwu B, Cherniack NS (1996) $\mathrm{CO}_{2}$-induced c-fos expression in the CNS catecholaminergic neurons. Respir Physiol 105:3545. CrossRef Medline

Hertz L, Lovatt D, Goldman SA, Nedergaard M (2010) Adrenoceptors in brain: cellular gene expression and effects on astrocytic metabolism and $[\mathrm{Ca}(2+)]$ i. Neurochem Int 57:411-420. CrossRef Medline

Hokfelt T, Fuxe K, Goldstein M, Johansson O (1974) Immunohistochemi- cal evidence for the existence of adrenaline neurons in the rat brain. Brain Res 66:235-251. CrossRef

Huang HP, Zhu FP, Chen XW, Xu ZQ, Zhang CX, Zhou Z (2012) Physiology of quantal norepinephrine release from somatodendritic sites of neurons in locus coeruleus. Front Mol Neurosci 5:29. CrossRef Medline

Inoue W, Baimoukhametova DV, Füzesi T, Cusulin JI, Koblinger K, Whelan PJ, Pittman QJ, Bains JS (2013) Noradrenaline is a stress-associated metaplastic signal at GABA synapses. Nat Neurosci 16:605-612. CrossRef Medline

Jansen AS, Nguyen XV, Karpitskiy V, Mettenleiter TC, Loewy AD (1995) Central command neurons of the sympathetic nervous system: basis of the fight-or flight response. Science 270:644-646. CrossRef Medline

Kaur S, Pedersen NP, Yokota S, Hur EE, Fuller PM, Lazarus M, Chamberlin NL, Saper CB (2013) Glutamatergic signaling from the parabrachial nucleus plays a critical role in hypercapnic arousal. J Neurosci 33:7627-7640. CrossRef Medline

Lin JY (2011) A user's guide to channelrhodopsin variants: features, limitations and future developments. Exp Physiol 96:19-25. CrossRef Medline

Lorang D, Amara SG, Simerly RB (1994) Cell-type-specific expression of catecholamine transporters in the rat brain. J Neurosci 14:4903-4914. Medline

Madden CJ, Sved AF (2003) Cardiovascular regulation after destruction of the $\mathrm{C} 1$ cell group of the rostral ventrolateral medulla in rats. Am J Physiol Heart Circ Physiol 285:H2734-H2748. CrossRef Medline

Marina N, Abdala AP, Korsak A, Simms AE, Allen AM, Paton JF, Gourine AV (2011) Control of sympathetic vasomotor tone by catecholaminergic C1 neurones of the rostral ventrolateral medulla oblongata. Cardiovasc Res 91:703-710. CrossRef Medline

Milner TA, Abate C, Reis DJ, Pickel VM (1989) Ultrastructural localization of phenylethanolamine $\mathrm{N}$-methyltransferase-like immunoreactivity in the rat locus coeruleus. Brain Res 478:1-15. CrossRef Medline

Mitchell DA, Lambert G, Secher NH, Raven PB, van Lieshout J, Esler MD (2009) Jugular venous overflow of noradrenaline from the brain: a neurochemical indicator of cerebrovascular sympathetic nerve activity in humans. J Physiol 587:2589-2597. CrossRef Medline

Moreira TS, Takakura AC, Colombari E, Guyenet PG (2006) Central chemoreceptors and sympathetic vasomotor outflow. J Physiol 577:369386. CrossRef Medline

Morilak DA, Fornal CA, Jacobs BL (1987a) Effects of physiological manipulations on locus coeruleus neuronal activity in freely moving cats: II. Cardiovascular challenge. Brain Res 422:24-31. CrossRef Medline

Morilak DA, Fornal CA, Jacobs BL (1987b) Effects of physiological manipulations on locus coeruleus neuronal activity in freely moving cats: III. Glucoregulatory challenge. Brain Res 422:32-39. CrossRef Medline

Morrison SF, Callaway J, Milner TA, Reis DJ (1989) Glutamate in the spinal sympathetic intermediolateral nucleus: localization by light and electron microscopy. Brain Res 503:5-15. CrossRef Medline

Murase S, Inui K, Nosaka S (1994) Baroreceptor inhibition of the locus coeruleus noradrenergic neurons. Neuroscience 61:635-643. CrossRef Medline

Neverova NV, Saywell SA, Nashold LJ, Mitchell GS, Feldman JL (2007) Episodic stimulation of alphal-adrenoreceptors induces protein kinase C-dependent persistent changes in motoneuronal excitability. J Neurosci 27:4435-4442. CrossRef Medline

O'Donnell J, Zeppenfeld D, McConnell E, Pena S, Nedergaard M (2012) Norepinephrine: a neuromodulator that boosts the function of multiple cell types to optimize CNS performance. Neurochem Res 37:2496-2512. CrossRef Medline

Paxinos G, Franklin KBJ (2004) The mouse brain in stereotaxic coordinates. Amsterdam: Elsevier.

Petreanu L, Huber D, Sobczyk A, Svoboda K (2007) Channelrhodopsin-2assisted circuit mapping of long-range callosal projections. Nat Neurosci 10:663-668. CrossRef Medline

Petreanu L, Mao T, Sternson SM, Svoboda K (2009) The subcellular organization of neocortical excitatory connections. Nature 457:1142-1145. CrossRef Medline

Pieribone VA, Aston-Jones G (1991) Adrenergic innervation of the rat nucleus locus coeruleus arises predominantly from the $\mathrm{C} 1$ adrenergic cell group in the rostral medulla. Neuroscience 41:525-542. CrossRef Medline

Ritter S, Llewellyn-Smith I, Dinh TT (1998) Subgroups of hindbrain cate- 
cholamine neurons are selectively activated by 2-deoxy-D-glucose induced metabolic challenge. Brain Res 805:41-54. CrossRef Medline

Robertson SD, Plummer NW, de Marchena J, Jensen P (2013) Developmental origins of central norepinephrine neuron diversity. Nat Neurosci 16:1016-1023. CrossRef Medline

Schiltz JC, Sawchenko PE (2007) Specificity and generality of the involvement of catecholaminergic afferents in hypothalamic responses to immune insults. J Comp Neurol 502:455-467. CrossRef Medline

Schreihofer AM, Stornetta RL, Guyenet PG (1999) Evidence for glycinergic respiratory neurons: Bötzinger neurons express mRNA for glycinergic transporter 2. J Comp Neurol 407:583-597. CrossRef Medline

Sevigny CP, Bassi J, Teschemacher AG, Kim KS, Williams DA, Anderson CR, Allen AM (2008) C1 neurons in the rat rostral ventrolateral medulla differentially express vesicular monoamine transporter 2 in soma and axonal compartments. Eur J Neurosci 28:1536-1544. CrossRef Medline

Shu Y, Yu Y, Yang J, McCormick DA (2007) Selective control of cortical axonal spikes by a slowly inactivating $\mathrm{K}+$ current. Proc Natl Acad Sci U S A 104:11453-11458. CrossRef Medline

Sorg O, Magistretti PJ (1991) Characterization of the glycogenolysis elicited by vasoactive intestinal peptide, noradrenaline and adenosine in primary cultures of mouse cerebral cortical astrocytes. Brain Res 563:227-233. CrossRef Medline

Stornetta RL, Guyenet PG (1999) Distribution of glutamic acid decarboxylase mRNA-containing neurons in rat medulla projecting to thoracic spinal cord in relation to monoaminergic brainstem neurons. J Comp Neurol 407:367-380. CrossRef Medline

Stornetta RL, Sevigny CP, Guyenet PG (2002a) Vesicular glutamate transporter DNPI/VGluT2 mRNA is present in $\mathrm{C} 1$ and several other groups of brainstem catecholaminergic neurons. J Comp Neurol 444:191-206. CrossRef Medline

Stornetta RL, Sevigny CP, Schreihofer AM, Rosin DL, Guyenet PG (2002b) Vesicular glutamate transporter DNPI/GLUT2 is expressed by both C1 adrenergic and nonaminergic presympathetic vasomotor neurons of the rat medulla. J Comp Neurol 444:207-220. CrossRef Medline

Stornetta RL, Macon CJ, Nguyen TM, Coates MB, Guyenet PG (2013) Cholinergic neurons in the mouse rostral ventrolateral medulla target sensory afferent areas. Brain Struct Funct 218:455-475. CrossRef Medline

Teppema LJ, Veening JG, Kranenburg A, Dahan A, Berkenbosch A, Olievier C (1997) Expression of $c$-fos in the rat brainstem after exposure to hypoxia and to normoxic and hyperoxic hypercapnia. J Comp Neurol 388:169190. CrossRef Medline

Verberne AJ, Sartor DM (2010) Rostroventrolateral medullary neurons modulate glucose homeostasis in the rat. Am J Physiol Endocrinol Metab 299:E802-E807. CrossRef Medline

Verberne AJ, Stornetta RL, Guyenet PG (1999) Properties of C1 and other ventrolateral medullary neurones with hypothalamic projections in the rat. J Physiol 517:477-494. CrossRef Medline

Williams JT, North RA, Shefner SA, Nishi S, Egan TM (1984) Membrane properties of rat locus coeruleus neurones. Neuroscience 13:137-156. CrossRef Medline

Yuan PQ, Yang H (2002) Neuronal activation of brain vagal-regulatory pathways and upper gut enteric plexuses by insulin hypoglycemia. Am J Physiol Endocrinol Metab 283:E436-E448. CrossRef Medline

Zhang YP, Oertner TG (2007) Optical induction of synaptic plasticity using a light-sensitive channel. Nat Methods 4:139-141. CrossRef Medline 